\title{
Regulatory T Cell Therapy of Graft-versus-Host Disease: Advances and Challenges
}

\author{
Mehrdad Hefazi ${ }^{1}$, Sara Bolivar-Wagers ${ }^{2}$ and Bruce R. Blazar ${ }^{2, *(D)}$ \\ 1 Division of Hematology, Mayo Clinic, Rochester, MN 55905, USA; hefazitorghabeh.mehrdad@mayo.edu \\ 2 Division of Blood and Marrow Transplant \& Cellular Therapy, Department of Pediatrics, \\ University of Minnesota, Minneapolis, MN 55454, USA; boliv004@umn.edu \\ * Correspondence: blaza001@umn.edu; Tel.: +612-626-1926; Fax: +612-626-2913
}

Citation: Hefazi, M.; Bolivar-Wagers, S.; Blazar, B.R. Regulatory T Cell Therapy of Graft-versus-Host Disease: Advances and Challenges. Int. J. Mol. Sci. 2021, 22, 9676. https://doi.org/ $10.3390 /$ ijms 22189676

Academic Editor: Tomomi Toubai

Received: 9 August 2021

Accepted: 4 September 2021

Published: 7 September 2021

Publisher's Note: MDPI stays neutral with regard to jurisdictional claims in published maps and institutional affiliations.

Copyright: (c) 2021 by the authors. Licensee MDPI, Basel, Switzerland. This article is an open access article distributed under the terms and conditions of the Creative Commons Attribution (CC BY) license (https:// creativecommons.org/licenses/by/ $4.0 /)$.

\begin{abstract}
Graft-versus-host disease (GVHD) is the leading cause of morbidity and mortality after allogeneic hematopoietic stem cell transplantation (allo-HSCT). Immunomodulation using regulatory T cells (Tregs) offers an exciting option to prevent and/or treat GVHD as these cells naturally function to maintain immune homeostasis, can induce tolerance following HSCT, and have a tissue reparative function. Studies to date have established a clinical safety profile for polyclonal Tregs. Functional enhancement through genetic engineering offers the possibility of improved potency, specificity, and persistence. In this review, we provide the most up to date preclinical and clinical data on Treg cell therapy with a particular focus on GVHD. We discuss the different Treg subtypes and highlight the pharmacological and genetic approaches under investigation to enhance the application of Tregs in allo-HSCT. Lastly, we discuss the remaining challenges for optimal clinical translation and provide insights as to future directions of the field.
\end{abstract}

Keywords: allogeneic hematopoietic stem cell transplantation; graft-versus-host disease; regulatory T cells; GVHD; Treg

\section{Introduction}

Allogeneic hematopoietic stem cell transplantation (allo-HSCT) is used as a curative therapy for various hematological and non-hematological disorders. However, its efficacy is limited by the occurrence of graft-versus-host disease (GVHD), which remains the leading cause of morbidity and mortality after allo-HSCT. Prophylactic GVHD regimens utilize nonspecific immune suppression, leaving cancer patients at risk of relapse, lifethreatening infections, and drug toxicities. Corticosteroids remain the first-line treatment for both acute and chronic GVHD; however, less than 50\% of patients achieve durable responses [1,2]. Currently, Ruxolitinib is the only U.S. Food and Drug Administration (FDA)-approved drug for acute GVHD in patients failing corticosteroids [3]. At this time, only Ibrutinib and Belumosudil (KD025) are FDA-approved drugs for chronic GVHD patients failing corticosteroids or $>1$ line of prior therapy [4,5]. Ruxolitinib is being evaluated by the FDA as consideration for approval based on the recently published REACH3 study (NCT03112603) [6]. New treatments are critically needed to reduce GVHD prevalence and severity in an effort to improve HSCT patient outcomes, as well as reduce toxicities associated with long-term drug therapy.

Regulatory T cells (Tregs) are critical for immune homeostasis and tolerance induction after HSCT. Anticipated advantages are permanency of effect, induction of tolerance that obviates the need for ongoing drug therapy, and potential for tissue repair [7-9]. Strategies to enhance Treg numbers and function have been adopted from preclinical studies and are showing potential in the clinic $[10,11]$. Preclinical studies have shown that the Treg function and specificity can be enhanced by pharmacological agents or via genetic modifications. This review highlights recent preclinical and clinical advances in Treg therapy for GVHD and discusses remaining challenges for clinical translation. 


\section{Treg Subtypes and Their Applications}

CD4 Tregs are the most well-studied immune regulatory $\mathrm{T}$ cells, and are characterized by co-expression of CD4, CD25, and the transcription factor Forkhead box protein 3 (Foxp3) [12-14]. This subset in human comprise $2-4 \%$ of circulating $\mathrm{CD}^{+} \mathrm{T}$ cells; compared to $5-10 \%$ in secondary lymphoid organs of rodents $[12,13,15-17]$. Based on their origin, Tregs can be classified as those having developed in the thymus [known as thymic Tregs (tTregs) or natural Tregs (nTregs)] or induced in vivo in peripheral tissues from conventional $\mathrm{T}$ cells (Tcons) under non-inflammatory or inflammatory conditions and typically on mucosal surfaces [known as peripheral Tregs (pTregs)] or those induced from Tcons in vitro [known as induced Tregs (iTregs)] [18]. T cell receptors (TCRs) of tTregs generally recognize self-antigens, while iTregs tend to express TCRs specific for foreign antigens [19-22]. Tregs can be further classified through functional and phenotypic distinctions. The differentiation of Tregs is accompanied by functional diversification, which parallels the pattern of differentiation in Tcons [23-27]. These subsets of Treg cells specialize at the regulation of specific classes of immune responses. Different strategies are thus under investigation with the aim to tailor the in vitro polarization of Treg products for adoptive transfer in GVHD (Table 1).

The stability of Foxp3 expression is controlled by the methylation status of genes in a Treg-specific demethylation region (TSDR). The promotor and TSDR within the 2nd conserved non-coding sequence (CNS2) is completely demethylated in tTregs, resulting in a stable Foxp3 expression and suppressor function [28-30]. iTregs, on the other hand, lack the tTreg transcription factor signature (Eos, Lef1, Satb1, IRF4, GATA1; known as "locked-in" signature) and exhibit a partially demethylated TSDR [28-31]. As such, iTregs can be inherently unstable and lose their Foxp3 expression under certain proinflammatory conditions [32-35].

Table 1. Phenotypic and functional heterogeneity of regulatory T cells and their role in GVHD.

\begin{tabular}{|c|c|c|c|c|c|}
\hline Subtype & Origin & Phenotype & $\begin{array}{l}\text { Activation } \\
\text { Factors }\end{array}$ & $\begin{array}{l}\text { Suppressive } \\
\text { Functions * }\end{array}$ & Role in HSCT \\
\hline CD4 tTreg & Thymus & $\begin{array}{l}\text { CD25 }^{+} \\
\text {Foxp3 }^{+} \\
\text {CD127 } \\
\text { Helios }^{+}\end{array}$ & $\begin{array}{c}\mathrm{IL}-2 \\
\mathrm{TCR} / \mathrm{CD} 28\end{array}$ & $\begin{array}{l}\text { Cell-cell contact } \\
\text { IL-10 } \\
\text { TGF- } \beta \\
\text { Poor Tcon priming by } \\
\text { APCs }\end{array}$ & 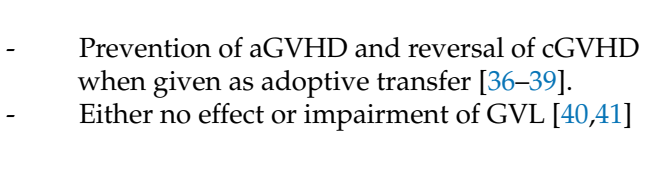 \\
\hline CD8 iTreg & Periphery & $\begin{array}{l}\text { CD25 }^{+} \\
\text {Foxp3 }^{+} \\
\text {CD127 } \\
\text { Helios }^{-/+}\end{array}$ & $\begin{array}{l}\text { IL-2 } \\
\text { TGF } \beta\end{array}$ & $\begin{array}{l}\text { Cell-cell contact } \\
\text { IL-10 } \\
\text { TGF- } \beta\end{array}$ & $\begin{array}{l}\text { Potential role in adoptive transfer for aGVHD } \\
\text { prevention [42] }\end{array}$ \\
\hline $\begin{array}{l}\text { Type } 1 \\
\text { Regulatory } \\
\text { T Cell }(\operatorname{Tr} 1)\end{array}$ & Periphery & $\begin{array}{l}\mathrm{CD}^{2} 5^{+/-} \\
\text {Foxp3 } \\
\text { CD49 } \beta^{+} \\
\text {Lag3 }^{+}\end{array}$ & $\begin{array}{c}\text { Tbet } \\
\text { Blimp-1 }\end{array}$ & $\begin{array}{l}\text { IL-10 }>>\text { TGF- } \beta \\
\text { Granzyme B } \\
\text { CTLA- } 4\end{array}$ & $\begin{array}{ll}\text { - } & \text { Antigen-dependent suppression, hence } \\
\text { reduced global immunosuppression }[43,44] \\
\text { - } \quad \text { Important role in aGVHD when donor tTregs } \\
\text { are profoundly deficient }[45] \\
\text { - } \quad \text { Potential role in GVL }[46,47]\end{array}$ \\
\hline $\begin{array}{l}\text { Follicular } \\
\text { Regulatory } \\
\text { T Cell } \\
\text { (TFR) }\end{array}$ & Thymus & $\begin{array}{l}\text { CD25 }^{\text {lo }} \\
\text { Foxp }^{3+} \\
\text { CXCR5 }^{+} \\
\text {Bcl6 }^{+} \\
\text {ICOS }^{\text {hi }}\end{array}$ & $\begin{array}{l}\text { mTOR } \\
\text { STAT3 } \\
\text { TCF-1 }\end{array}$ & $\begin{array}{l}\text { IL-10 } \\
\text { Granzyme B } \\
\text { TGF- } \beta \\
\text { CTLA-4 }\end{array}$ & $\begin{array}{l}\text { Important role in cGVHD and autoimmunity } \\
{[48,49]}\end{array}$ \\
\hline CD8 iTregs & Periphery & $\begin{array}{l}\text { Foxp3 }^{+} \\
\text {CD28 }\end{array}$ & $\begin{array}{l}\text { IL-2 } \\
\text { TGF } \beta\end{array}$ & $\begin{array}{c}\text { IL-4 } \\
\text { IL-10 } \\
\text { TGF- } \beta \\
\text { Perforin/Granzyme } \\
\text { Fas-L/Fas }\end{array}$ & Potential role in GVHD and GVL $[45,50]$ \\
\hline
\end{tabular}

Abbreviations: aGVHD: acute GVHD; cGVHD: chronic GVHD; GVHD: graft-versus-host disease; GVL: graft-versus-leukemia; iTreg: induced Treg; tTreg: thymic-derived Treg. * In vitro and in vivo suppressor functions listed are not all inclusive. 


\subsection{CD4tTregs}

CD4 tTregs are the most well-studied immune regulatory T cells. It is clearly established that CD4 $\mathrm{t}$ Tregs are essential for the maintenance of immune homeostasis and self-tolerance [51-53]. Mice lacking FoxP3 protein (scurfin), known as scurfy mice, have no Tregs, defective $\mathrm{T}$ cell tolerance and a generalized autoimmune disease that is severe and X-linked lymphoproliferative syndrome $[12,13,16]$. In patients FoxP3 mutation and Treg deficiency results in an autoimmune disease known as IPEX, immunodysregulation polyendocrinopathy enteropathy, X-linked [51].

Preclinical studies have shown that adoptive transfer of tTregs can control allograft rejection and GVHD by limiting alloimmune responses [54-57]. However, translation to the clinic has been challenging due to the low frequency of human tTregs (typically $2-4 \%$ of $\mathrm{CD}^{+} \mathrm{T}$ cells) in the peripheral blood, and that the phenotypic profile of human tTregs is not as readily distinguished in peripheral blood as in the spleen and lymph nodes of mice [15]. Currently, most studies isolate human Tregs from peripheral blood, although third-party umbilical cord blood (UCB) derived Tregs have been successfully used in clinical trials [36]. The advantages of using UCB are higher frequency of $\mathrm{CD} 4^{+} \mathrm{CD} 25^{\text {bright }}$ Treg cells and a reduced likelihood of isolating CD25 $5^{+}$Tcons due to the lower foreign antigen exposure and general immune regulatory environment of the fetus. In a phase I trial of ex vivo expanded polyclonal recipient Tregs infused into patients receiving living donor kidney transplant, the adoptive transfer of these CD4 iTregs post-transplant was safe with no adverse effects or rejection up to two years post-transplant [58].

Despite their relatively strong lineage fidelity, some but not all studies indicate that tTreg can lose stability and Foxp3 expression under certain conditions in an inflammatory environment, with consequent loss of immunosuppressive capacity $[33,35,59,60]$. Several groups have reported that TCR-stimulated tTregs can be converted to Th17 cells in the presence of IL-6 in vitro that can be reduced by exposure to TGF $\beta$ [61-63]. Decreased Foxp3 expression can cause immune disease by subverting the suppressive function of tTregs leading to Th2 cell generation [64]. Loss of function or elimination of Tregs expressing the Th1 associated T-box transcription factor T-bet results in severe Th1 autoimmunity [65]. Therefore, it is desirable to find an approach that can sustain the stability and function of tTregs in the inflammatory condition. Previous data have shown that all-trans retinoic acid (ATRA), the major vitamin A metabolite, increases histone acetylation on the Foxp3 gene promoter and suppresses differentiation of tTregs to Th17 cells in an inflammatory milieu $[63,66,67]$. Taken together, CD4 tTregs likely represent a more reliable regulatory cell type for adoptive transfer owing to their greater expansion potential, functional stability, and proven track record of safety in multiple clinical trials (see below).

\subsection{CD4 iTregs}

The relative scarcity of tTregs in the peripheral blood and the time and cost of in vitro Treg expansion protocols significantly limit their clinical usefulness. Thus, several groups have explored an alternative way to induce Tcons in vitro to generate iTregs. The main advantages of this approach are that iTregs can be generated in relatively high numbers, overcoming the limitations of the small starting population of tTregs and in vitro expansion and iTregs can be highly effective in tolerance induction to colitis that is further augmented by combining with tTregs $[68,69]$. CD4 iTregs can be generated under several different conditions, the most common of which include the culture of Tcons with TGF- $\beta$ or retinoid acid. Foxp3 stabilization can also be bolstered by addition of compounds such as rapamycin, vitamin $C$ that increases the activity of the ten-eleven translocation enzyme Tet2, or combination of demethylating agents and histone deacetylase inhibitors, amongst others [59,69-76]. Building on these efforts, Hippen and colleagues have developed a protocol for expanding large numbers of CD4 iTregs from Tcons in the presence of rapamycin, TGF- $\beta$, and IL-2, suitable for clinical trials [43]. 


\subsection{CD8 iTregs}

CD8 iTregs are induced in the periphery early after allo-HSCT and comprise a significant percentage of all Treg subsets [77]. The defining markers of CD8 iTregs are still under study and more research will be necessary to reach a consensus [78]. CD8 iTregs have been reported to engage in multiple cell-dependent and independent mechanisms to mediate immune suppression and homeostasis [79-83]. Using mice that were unable to generate both CD4 and CD8 iTregs, Beres et al. showed that iTreg-deficient mice had increased expansion of alloreactive T cells, and that CD8 iTregs in the absence of CD4 iTregs had the capacity to prevent GVHD severity [77]. Vitamin C given in vivo can induce and stabilize CD8 iTregs that diminish GVHD without loss of anti-tumor responses [84]. Deletion of Janus-activated kinase-2 (JAK2) in CD8 iTregs stabilized Foxp3 and increased their efficacy in preventing GVHD [84]. The adoptive transfer of in vitro generated CD8 iTregs can ameliorate GVHD by targeting alloreactive Tcon activation and proliferation through a CTLA-4 dependent mechanism [83]. The adoptive transfer of in vitro generated human CD8 iTregs have promoted tolerance without abrogating the graft anti-tumor responses in a humanized mouse model of GVHD [83]. Small molecule inhibitor of signal transducer and activator of transcription factor 3 (STAT3) polarized human iTregs generated from Tcons to express STAT5, augmenting iTreg stability and further reducing GVHD $[85,86]$.

Antigen-specific CD4 iTregs selectively prevented GVHD via a mechanism of linkedsuppression $[50,87]$. Adoptively transferred CD4 iTregs have a potent capacity to inhibit GVHD, but in the process, develop impaired graft-versus-leukemia (GVL) capacity [50]. In contrast CD8 iTregs decreased GVHD albeit more modestly than CD4 iTregs but maintained GVL responses [50]. Combined adoptive transfer of both CD4 and CD8 iTreg was superior to either cell type alone in improving the outcome of allo-HSCT by virtue of more potent GVHD and GVL effects [50]. Altogether, these findings highlight the role of iTregs in mitigating GVHD and offer potential strategies for its therapeutic use. Future work will involve the investigation of unique markers to identify iTreg subsets with their associated functions and identification of optimal strategies to induce, stabilize, and expand CD8 iTregs for use in the clinic.

\subsection{Type 1 Regulatory (Tr1) Cells}

Type 1 regulatory (Tr1) cells are a class of regulatory T cells, distinct from Tregs, with high IL-10, interferon-gamma (IFN $\gamma$ ), transforming growth factor-beta (TGF $\beta$ ), no IL-4 or IL-17 and low/absent IL-2production; Tr1 cells express CD $4^{+} \mathrm{CD} 49 \beta^{+} \mathrm{Lag} 3^{+}$and have transient and lower level FoxP3 with activation [88-90]. Tr1 cells require the transcription factors Tbet and B lymphocyte-induced maturation protein-1 (blimp-1), while the T-box transcription factor eomesodermin (Eomes) is essential for long term persistence [91]. Tr1 cells assist in maintaining immunological homeostasis and promoting tolerance [92]. The suppressive role of $\operatorname{Tr} 1$ cells is highlighted in settings with low to negligible levels of $\mathrm{CD}^{+}{ }^{+} \mathrm{Foxp}^{+}$Tregs. In acute GVHD, Tr1 become the main Treg subset and $\operatorname{Tr} 1$ deficiency leads to GVHD progression [91]. Tr1 cell can secrete TGF $\beta$ to inhibit both effector T cells and APCs, granzyme B to mediate APC cytotoxicity, and express cytotoxic T-lymphocyte associated protein 4 (CTLA-4) and programmed death 1 (PD-1) to target effector T cell activation $[89,93,94]$.

To determine whether Tr1 cells could be used therapeutically, groups are using multiple strategies that range from in vitro gene editing to increasing $\operatorname{Tr} 1$ numbers in vivo. IL-10 and IL-10 inducing agents along with immunosuppressants, anti-CD3 antibodies, and tolerogenic DCs have shown promising results in $\operatorname{Tr} 1$ induction and GVHD prevention $[89,90,95,96]$. Tr1 cells are expressed at low frequency in vivo. Allogeneic donor $\mathrm{CD}^{+} \mathrm{T}$ cells cultured with host APCs in the presence of IL-10 generate Tr1 cells hyporesponsive to host alloantigens (termed Tallo-10 cells) [97,98]. IFN $\alpha$ is synergistic with IL-10 in inducing Tr1 cells from UCB [98]. Since IL-10 receptor expression is required for $\operatorname{Tr} 1$ cells, tolerogenic dendritic cells (DCs) that express immunoglobulin-like transcript 4 (ILT4), HLA-G and overexpress IL-10 have been used to drive the generation of $\operatorname{Tr} 1$ cells from 
Tcons. A sizable number of $\operatorname{Tr} 1$ can be generated in vitro from Tcons by inducing stable and sustained IL-10 overexpression in CD4 Tcons that suppress T cells in vivo while unexpectedly killing myeloid cells in an HLA class I-dependent but Ag-independent manner [47].

In preclinical model, Tr1 cells improved acute GVHD outcome [99]. In the clinic, delayed post-transplant in vivo infusion of Tallo-10 cells has been shown to be tolerogenic in some patients who had received haploidentical transplant [100]. The goal of current clinical trials is to determine whether Tr1 cell products are safe and tolerable. In T-allo10 trial (NCT03198234), a cell product containing 15\% Tr1 cells is infused a day prior to patients undergoing allo-HSCT. Preliminary results are encouraging as the T-allo10 product is tolerable thus far and Tr1 cells appear to have long term persistence [101]. Future clinical trials will likely involve testing the safety and efficacy of genetically engineered $\operatorname{Tr} 1$ cells, antigen-specific Tr1 cells, and their applications beyond HSCT.

\subsection{Follicular Regulatory T (TFR) Cells}

Follicular regulatory $\mathrm{T}$ (TFR) cells share phenotypic characteristics with $\mathrm{T}$ follicular helper cells (TFH) and CD4 tTregs, yet TFR cells are very distinct from both. TFRs coexpress Foxp3 and B-cell lymphoma protein-6 (Bc16) and localize to germinal centers (GCs) due to their expression of CXCR5; however, they originate from thymic-derived Foxp $3^{+}$ precursors, and not naïve or TFH cells [102]. Other cell surface determinants that are present on TFR cells are T cell inducible costimulator (ICOS), CD40L, and PD-1, with the latter restraining TFR function [103]. This specialized subset of regulatory cells prevents TFH cells from providing support to B cell maturation in GCs, thereby playing an important role in antibody production and regulation of autoimmunity. TFR cells suppress IL-21 and IL-4 production by TFH cells, and inhibit class switch recombination and antibody production by B cells [104-106].

The imbalance between TFH and TFR cells plays an important role in some models of chronic GVHD [48,49]. This is evidenced by an increase in TFH and B cells in GCs, along with low TFR cell and TFR/TFH ratio [48]. McDonald et al. showed that daily therapeutic IL-2 complexed with JES6- anti-IL2 antibody increased TFR frequency while TFH numbers were consequently reduced in mice [49]. Consistent with these data, chronic GVHD patients have high circulating TFH cells and are Treg deficient [107,108]. Low dose IL-2 infusion restored Treg homeostasis and diminished clinical manifestations [108,109]. Although ascribed to the preferential stimulation of CD25 hi TFR cells, TFRs do not express CD25 and hence do not have a high affinity IL-2 receptor. Sakaguchi and colleagues reported a distinct CD25- TFR subpopulation [110]. At the same time, Klatzmann and co-workers showed that TFR cells are CD25- , while Botta et al. demonstrated that TFR cells are CD25 low and that IL-2 prevents TFRs from developing by Blimp-1 mechanism [111,112]. As the intermediate affinity IL-2 receptor beta chain (CD122) is expressed, IL-2 may support TFR expansion via an IL-2-STAT5 axis.

The immunomodulatory effect of TFR cells leads to a distinctive durable inhibition of TFH and B cells, while leaving global effector molecules and metabolic pathways intact [103]. TFRs may therefore be beneficial to patients with chronic GVHD, although obtaining sufficient number of TFR cells for adoptive transfer is an obvious challenge. With the advent of genetic engineering techniques, it may be possible to use polyclonal Tregs, and modify them so that they become TFRs. Indeed, Kim et al. showed that forced expression of CXRCR5 via retroviral transduction drives TFR-like features in Foxp3 Tregs. The expression of CXCR5 and Foxp3 appeared to be stable after adoptive transfer, leading to an effective suppression of antibody production from B cells stimulated with TFH cells [113]. Complementary or additive to low dose IL-2, the adoptive transfer of Tregs or the more specialized TFR cells could thus have a high potential in chronic GVHD, although more work is needed to determine how to best deploy TFR cells therapeutically. 


\section{Genetic Engineering Strategies}

\subsection{Antigen Specificity}

Antigen-specific Tregs have garnered interest in the Treg field because of their increased potency compared to polyclonal Tregs on a per cell basis and their potential for reduced off-target immunosuppression [114]. Proof-of-principle experiments have shown that alloantigen-reactive Tregs can be expanded using donor APCs such as DCs or B cells [79,114-116]. Ex vivo expansion in the presence of the antigen of interest would accomplish this goal. Treg genome editing could be advantageous as it would confer antigen specificity to a larger Treg population rather than amplifying rare antigen-specific precursor cells achievable by introduction of engineered TCRs or a chimeric antigen receptor (CAR) that, for example, is directed to an MHC molecule [117-119].

\subsubsection{TCR-Engineered Tregs}

The use of TCRs represents a physiological way of activating T cells and allows for targeting of intracellular antigens presented by HLA molecules. This approach has been successfully tested in various preclinical models of autoimmune disorders and transplantation [87,120-123]. Tsang et al. showed that adoptively transferred allo-specific murine CD4 tTregs generated by either donor APCs or transduction of a TCR reactive against donor antigens could promote indefinite heart allograft survival, even in completely mismatched mouse strains [123]. In another study chicken ovalbumin (OVA) specific CD4 iTregs generated from OVA-reactive OT-II TCR transgenic T cells efficiently prevented GVHD induced by polyclonal T effector cells in the allogeneic recipients that express OVA protein, but not in OVA(-) recipients [87]. The efficacy of these antigen-specific CD4 iTregs was significantly higher than polyclonal CD4 iTregs. While these results are encouraging, the main limitations of the TCR-engineering strategy are MHC restriction, which limits their coverage to a certain MHC-bearing host (allo-HSCT) or donor (solid organ graft), along with the risk of mispairing the engineered TCR with the endogenous TCR, which can cause undesired reactivity and off-target effects [124,125]. However, the expression of a single antigen-specific TCR in Tregs that is directed toward a donor-host antigen disparity may hinder GVHD prevention in situations in which tissue-specific antigens are not represented in culture systems or there is skewing to an in vitro immunodominant antigen that is subdominant in vivo and potentially diverting Tregs away from their target antigens.

\subsubsection{Chimeric Antigen Receptor (CAR) Tregs}

The success of CAR T cells in hematological malignancies has generated interest in redirecting Treg specificity to inciting antigens that contribute to autoimmunity and transplantation rejection [126,127]. CARs are synthetic receptors that consist of an extracellular single chain variable fragment (scFv) linked with an intracellular CD3 activation domain. Depending on the CAR generation one or more costimulatory domains will deliver intracellular signals to T cells. CARs are advantageous compared to TCR-guided approaches because of their ability to recognize antigen directly on the cell surface in a non-MHC restricted manner [128]. Recently, groups have targeted the human leukocyte antigen (HLA) present on allografts and absent in recipients to redirect Treg specificity to promote graft tolerance and reduce GVHD $[118,119,129,130]$. For example, anti-HLA-A2 CAR Tregs demonstrated superior function compared to polyclonal Tregs in suppressing xenogeneic GVHD and more potently reduced skin allograft rejection compared to polyclonal Tregs $[118,119,129,130]$. A phase $1 / 2$ a trial examining the safety profile of autologous anti-HLA-A2 CAR Treg cells for patients undergoing kidney transplantation is ongoing (NCT04817774).

Another antigen recently tested to redirect CAR Tregs in preclinical studies is the CD19 antigen expressed on B cells. Anti-CD19 CAR Tregs have been applied in humanized mouse GVHD models to demonstrate potent suppression of xenogeneic GVHD clinical manifestations (weights; GVHD scores), as well as demonstrated efficacy to decrease skin allograft rejection [131]. Ongoing efforts are focused on evaluating optimal CAR design 
for Tregs as different costimulatory domains affect Treg phenotype, function, and cytokine production $[132,133]$. Boroughs et al. found that the use of a 4-1BB-based CAR in Tregs reduced expression of suppressive cytokines and negatively affected their function in vitro and in vivo [132]. Confirming and expanding on these studies, Dawson et al. performed an extensive study on how different costimulatory domains, including CD28, ICOS, CTLA4, PD-1, GITR, OX40, 4-1BB, and TNFR2, modulate the function of an anti- HLA-A2 CAR in an allotransplantation model [133]. In contrast to anti-tumor CAR studies, the data showed that the CD28-encoding CAR was superior in vitro and in vivo in terms of proliferation, suppression and delay of GVHD symptoms. Interestingly, the 4-1BB-CAR and TNFR2-CAR expression negatively affected Treg function and stability, inducing methylation of the Foxp3 locus, downregulating the expression of Helios, and reducing suppressive function in vitro and in vivo [133]. In contrast to the findings of Dawson et al., Koristka et al. used a modular CAR technology called UniCAR and showed that CD28-based CARs might exert off-target activity and heightened cytolytic activity compared to 4-1BB based CARs [134]. CAR Treg design will continue to be optimized for potency, specificity, and persistence.

An important concern with adoptive Treg cell therapy is that infused cell product may contain potentially deleterious Tcon cells. Even when Tcon cells are rigorously excluded from the infusion product that can be accomplished by high-speed sorting as used by Orca Bio (final Orca-T product $\sim 93.8 \%$ Tregs), the safety of adoptively transferred Tregs may be challenged by the propensity of some Tregs to differentiate into Tcons under an inflammatory condition chrome [135]. The risk is arguably higher when Tregs are genetically edited to redirect their specificity. In fact, lineage tracing experiments have shown that Tregs carrying a TCR specific for an antigen expressed in the central nervous system had converted to Tcons and precipitated paralysis in a mouse model of multiple sclerosis [124]. Similar results were reported in a mouse model for autoimmune arthritis [136]. Therefore, production of genetically modified antigen-specific Tregs will require the use of improved protocols for the purification and amplification of Tregs to prevent contaminating Tcons with putative hazard.

\subsection{Foxp3 Gene Editing of Tcons to Generate Tregs}

Given the key role of Foxp3 in controlling Treg function, several groups have used genetic engineering to increase or stabilize its expression [137-140]. This strategy could allow high numbers of Tregs to be generated from Tcons, hence circumventing the need for isolation and expansion of polyclonal Tregs. Functional CD4 ${ }^{+}$Tregs from IPEX patients can be generated by ectopic expression of Foxp3 in Tcons [140]. Further, CRISPR-based Foxp3 gene editing by precise homology directed repair (HDR) was used to obtain Foxp3 expression in hematopoietic stem and progenitor cells (HSPCs) from IPEX patients; in vitro regulatory function of the edited cells was observed and HSPCs differentiation potential was preserved [138]. Edited cells demonstrated stable Foxp3 expression under inflammatory conditions and suppressed xenograft acute GVHD [141]. In a separate study, Wright and colleagues showed that retroviral mediated gene co-transfer of Foxp3 and a TCR could convert $\mathrm{CD}^{+}$Tcons into antigen-specific Tregs in mice capable of suppressing immune responses by T cells specific for a third-party antigen, albeit less potent than TCR-transduced natural Tregs [142]. The difference between engineered natural Tregs and Foxp3-converted $\mathrm{T}$ cells transduced with the same TCR may lie in the inability of the latter to exploit endogenous promoter and enhancer regions or a requirement for other factors to stabilize the Treg phenotype. To test this hypothesis, Fu et al. used a computational and experimental approach to reverse engineer the transcriptional regulatory network of Tregs [143]. These experiments showed that Foxp3 alone was not sufficient to "lock in" Treg cell signature, but a partially induced Treg profile could be stabilized by co-transduction with one of five transcription factors Eos, IRF4, GATA-1, Lef1, or Satb1 [143].

Epigenetic editing technology has also been used to upregulate or stabilize Foxp3 expression. Delivery of catalytically inactive CRISPR-Cas9 (dCas9) fused to the catalytic domain of histone acetyltransferase showed that histone acetylation targeted to the promoter 
locus was able to activate and stabilize Foxp3 levels in mice, even under inflammatory conditions [144]. Similarly, Foxp3 expression could be upregulated via dCas9 fused to a transcriptional activator and guide RNAs recognizing the Foxp3 promoter [145]. In contrast, Kressler et al. showed that epigenetic editing via CRISPR-dCas9-TET1 leads to stable TSDR demethylation and Foxp3 expression, but is not sufficient to convert Tcons into a fully functional Treg [146]. Such epigenetic editing approaches may thus need to be combined with other methods that augment iTreg function or stability.

\section{3. iPSC-Derived Tregs}

Induced pluripotent stem cells (iPSC) can be used as an alternative source of Tregs. Human iPSCs are generated from fibroblasts or cord blood cells and transduced with defined transcription factors to revert them into pluripotent stem cells [147]. These cells can then be used to form almost all cells of the body. In mice, iPCS-derived Tregs can be generated through transduction of Foxp3 and co-culture with stromal cells that express Notch ligand $[148,149]$. Additionally, TCR and Foxp3 gene-transduced iPSCs can be used to differentiate antigen-specific iPSC-Tregs. Adoptive transfer of antigen-specific iPSC derived Tregs has proven effective in a well-established antigen-induced arthritis model, as well as in a murine model of autoimmune diabetes $[148,149]$. As protocols for generating human iPSC-derived Tregs are being developed, comparative studies of CD4 tTregs and CD8 iTregs in terms of potency, stability, and longevity will be critical.

\subsection{Drug Resistant Tregs}

After allo-HSCT, many patients require ongoing immunosuppression to prevent or treat GVHD. Immunosuppressive drugs such as Cyclosporin, Tacrolimus, and corticosteroids can potently suppress $\mathrm{T}$ cell function and provoke lymphocyte apoptosis $[150,151]$ To address this limitation, several groups have genetically engineered $\mathrm{T}$ cells for resistant to these drugs, thereby permitting their preferential survival. Large-scale GMP-compliant CRISP/Cas9-mediated knock out of the glucocorticoid receptor and tacrolimus-binding protein has been used in the context of virus specific $T$ cells to confer drug resistance [152-154]. Similar strategies may be applied to adoptive Treg therapy in the future.

\section{IL-2 Modulation Strategies}

Exogenous IL-2 administration has been ascribed to be deleterious in GVHD owing to its ability to promote effector $\mathrm{T}$ cell function, although when given in high doses for several days beginning on transplant day 0 , allo-HSCT recipient mice had markedly diminished GVHD $[155,156]$. As a consequence of high-affinity CD25 expression on Tregs and NK cells compared to Tcons, low or ultra-low dose IL-2 preferentially stimulated Treg and CD56 ${ }^{\text {hi }} \mathrm{CD} 16^{-}$NK cell proliferation and promoted Treg stability without augmenting cytotoxic T cells $[108,109,157-160]$. Clinical trials have shown that prophylactic low dose IL-2 administration during the early post-transplant period could effectively enhance Treg expansion and decrease the incidence of acute and chronic GVHD [158,161]. An open-label controlled randomized trial of low-dose $\left(1 \times 10^{6} \mathrm{U} / \mathrm{d}\right)$ given for 2 weeks beginning on day 60 in allo-HSCT recipients showed that the IL-2 treated group had a significantly lower incidence of moderate-to-severe chronic GVHD (33\% vs. 57\%), accompanied by a significant increase in GVHD-free and GVHD progression-free survival at three years (47\% vs. 31\%) [161]. Low-dose IL-2 therapy also has been shown to be efficacious in the treatment of steroid-refractory chronic GVHD in phase I/II clinical trials [108,109,162].

IL-2 may activate effector T cells that have the potential to worsen GVHD and NK cells which have a low GVHD capacity [163]. IL-2 has a relatively short half-life $(<30 \mathrm{~min})$ and is rapidly excreted in the urine. Tregs can be preferentially stimulated by administering IL-2/anti-IL-2 antibody complexes or IL-2 fusion protein that has a prolonged half-life and lower IL-2 peak levels [164-166]. This approach has shown efficacy in experimental models of autoimmune diseases and solid organ transplantation [166-169]. In the context of HSCT, preclinical data has shown that IL-2/anti-IL-2 antibody complexes have the 
capacity to expand Tregs and ameliorate chronic GVHD, a low inflammatory disease, while aggravating acute GVHD, a high inflammatory disease [49]. Studies on the binding interaction of IL-2 with anti-IL-2 mAbs have shown that IL-2 can be mutated to selectively stimulate Tregs, CD8 T cells, or NK cells [160]. Selective Treg stimulation can be favored by mutating IL-2 to bind poorly to IL-2R- $\beta$ while retaining IL-2 binding to IL-2R- $\alpha$ chain [170]. Ongoing phase I/II clinical trials are currently testing molecularly engineered IL-2 with an increased half-life in patients with steroid-refractory chronic GVHD (NCT03422627) or systemic lupus erythematosus (NCT04680637 and NCT04433585).

In a different approach, investigators engineered a mutated IL-2 receptor beta chain (IL-2R $\beta, C D 122)$ that binds its IL-2 ortholog with high affinity. Transduction of the mutated IL-2R into tTregs enabled selective stimulation by exposure to orthogonal IL-2 in vitro and in vivo, with limited off-target effects and toxicity due to the negligible binding to a wildtype IL-2 receptor, suggesting a clinical strategy [171]. In a similar study, Hirai et al. introduced an orthogonal IL-2R- $\beta$ chain into Tregs and demonstrated that upon adoptive transfer in a murine mixed hematopoietic chimerism model, orthogonal IL-2 injection significantly promoted orthogonal IL- $2 \mathrm{R}^{+}$Treg proliferation without increasing other $T$ cell subsets [172]. Under nonmyeloablative conditions, this strategy facilitated donor hematopoietic cell engraftment followed by the acceptance of heart allografts.

\section{Treg Immunometabolism and GVHD}

Recent attention has been placed on understanding the immunometabolism of Tcons and Tregs, including those present during GVHD. Specific metabolic perturbations have been reported during GVHD [173-177]. While the metabolic profiles of effector T cells (Tcon) in GVHD are becoming clearer, much is left to understand regarding Treg generation, proliferation, stability, and suppression. T cells increase aerobic glycolysis, mitochondrial oxidative phosphorylation (OXPHOS), and glutaminolysis early after alloHSCT [173-179]. Unlike Tcons, Tregs preferentially use OXPHOS to exert their suppressive functions $[180,181]$. However, Tregs also need glycolysis to fuel the biosynthetic and energetic needs associated with proliferation and homing [182,183].

There is an interest in targeting metabolic pathways that preferentially modulate Treg while reducing or at least not potentiating alloreactive Tcons. One commonly used approach is mTOR inhibition, which targets glycolysis in rapidly proliferating alloreactive $\mathrm{T}$ cells during GVHD [184]. Rapamycin, an mTOR inhibitor, has been particularly successful compared to other immunosuppressants because of its potential to inhibit Tcons and to enhance Foxp3 expression and Treg suppressive function [185,186]. Treg access to, deficiency of and excess exposure to specific substrates and metabolites can alter Treg phenotype, function, proliferation, homing, and survival. The host microbiome production of unique metabolites can be protective during HSCT by shaping pTreg generation. Treg function can be potentiated in vivo by enhancing fatty acid oxidation (FAO) that can fuel OXPHOS. Butyrate, a short chain FA produced by Clostridia, increased colonic Tregs, although butyrate can also be acute GVHD protective in a Treg independent manner [187-191]. In chronic GVHD, high circulating levels of microbe-derived short chain FAs are associated with GVHD protection. Metformin, a 5' AMP-activated protein kinase (AMPK) activator and FAO promoting agent, led to decreased Th17 cells, increased Tregs, and reduced acute GVHD severity and prevalence [192]. Inhibiting fatty acid synthesis significantly decreased Th17 effectors while supporting the development of Foxp $3^{+}$Tregs. Additionally, inhibiting glutamine transporters or glutamine or glutamate metabolism shifted from Th1/Th17 effector T cells towards increased Treg [193-195].

Foxp3 expression suppresses glycolysis and drives OXPHOS. Murine iTreg induction relies on lipid oxidation for OXPHOS. In contrast to iTregs, murine tTregs engage in glycolysis and glutaminolysis at comparable levels to Teff cells despite maintained Foxp3 expression [196]. Exposure of murine tTregs to TGF- $\beta$ repressed phosphotidylinositol 3-kinase (PI3K)-mediated mTOR signaling, inhibited glucose transporter and the first enzymatic step in glycolysis, hexokinase-2 expression, resulting in metabolic reprogramming to 
favor OXPHOS [196]. In human ex vivo cultures, tTregs and iTregs utilize glycolysis upon activation. Nonetheless, inhibiting glucose metabolism by exposure of human tTregs and iTregs to 2-deoxy-D-glucose (2DG) had distinct effects [197]. At the time of human tTreg activation, 2DG treatment mediated by mTORC1 significantly reduced the proliferation and suppressor molecule expression (ICOS, CTLA-4) with minimal FOXP3 expression [197]. In contrast, 2DG modestly decreased the proliferation of iTregs during the induction phase and strongly reduced ICOS and FOXP3 expression. The addition of 2DG on day 3 post activation did not impact proliferation for either tTregs and iTregs. In contrast, adding 2DG to Th0 cultures impaired their expansion but not cytokine production. These data provide strategies to improve Treg generation and expansion, while minimizing naïve $\mathrm{T}$ cell expansion, pointing to an approach that would inhibit contaminating Teff cells but spare human tTregs and iTregs.

Treg metabolism also can be indirectly altered by targeting intracellular pathways and cellular structures. For example, localization of protein kinase C-theta (PKC- $\theta$ ) in Toncs is at the immunological synapse, the point of contact between T cells and APCs where bidirectional signaling can occur. In Tregs, PKC- $\theta$ is located in a distal pole complex. Disruption of the PKC- $\theta$ distal pole complex by a small molecule inhibitor such as AEB071 increased in vitro and in vivo Treg suppressor function associated with reduced mTORC2 and increased metabolic fitness, as evidenced by increased expression of nutrient receptors (and FA uptake) and the rate-limiting enzyme for FA oxidation, and OXPHOS [38]. Similar results were seen using an siRNA to vimentin, a cytoskeletal intermediate filament that can tether mitochondria, inhibiting mitochondria network formation by the fusion of membranes of two distinct mitochondria into a single energy efficient mitochondria.

In summary, immunometabolism offers a new avenue to potentially prevent and treat GVHD, while providing ways to enhance Treg cell therapies. A particular advantage of this approach is that many metabolic modulators are already approved by the U.S. FDA or in clinical trials and could be repurposed to expedite new therapies into clinic to improve HSCT patient outcomes.

\section{Translational Challenges}

The manufacturing process for adoptive cell therapy is known to be complex and costly, which subsequently influences the translational success of these products. Important challenges particular to the field of Treg therapy are discussed below.

\subsection{Treg Isolation and Purity}

A major Treg challenge is obtaining high-level purification from an infrequent starting population using good manufacturing process (GMP) techniques. Treg isolation can be done using magnetic (MACS) or fluorescence-activated cell sorting (FACS) $[10,42,198]$. MACS is performed in a closed, sterile system, which involves clinical-scale magnetic enrichment of cells and can quickly process high numbers of untouched cells. Although magnetic bead sorting for $\mathrm{CD} 4^{+} / \mathrm{CD} 25^{\mathrm{hi}}$ cells may incorporate $\mathrm{CD} 127^{\mathrm{lo}}$, purity may remain inadequate because activated naive and especially memory Tcons express CD25 and are therefore difficult to separate by MACS from CD25 hi Treg population. Including more surface markers (e.g., CD45RA ${ }^{+}, \mathrm{CD}_{4} 9 \mathrm{~d}^{-}$, and $\mathrm{CD} 39^{\mathrm{hi}}$ ), can result in a better defined and purer Treg population; however, when using MACS, there is a limit to the number of markers that can be included [199-202].

Compared to MACS, enrichment of Tregs by flow cytometry sorting enhances post-sort purity by allowing for additional selection markers and employing antigen density-defined cut-offs. This however significantly adds to the logistics and cost of Treg isolation including droplet-based sorting under GMP conditions and the requirement for GMP antibodies and flow sorter [203,204]. Currently, FACS equipment is not accepted as GMP-grade by many European regulatory authorities and is not suitable for scaling up in late-stage clinical trials. The newest generation of such droplet-based cell sorters attempts to fulfill GMP requirements, and these are being used in two clinical trials for allo-HSCT (NCT03802695 
and NCT04013685) [205]. Another potential alternative could be the use of microfluidic switch technologies, such as the MACSQuant ${ }^{\circledR \circledR}$ Tyto ${ }^{\circledR 囚}$ cell sorting platform, and fluidchannel sorters and technology developed by Orca Bio [37,135].

\subsection{Ex Vivo Expansion and Stability}

Freshly sorted Tregs have been used in the clinic [206]. Previous studies have demonstrated that a high ratio of Tregs to Tcons (e.g., 1:1 or 1:2) may be needed to mediate tolerance $[36,42,206-208]$. In lymphopenic allo-HSCT recipients, the transfer of freshly sorted Tregs two days before Tcons allowes for in vivo expansion. Myeloablation induces the highest degree of lymphopenia. For patients with autoimmunity, solid organ transplant or non-myeloablated allo-HSCT, it is uncertain that the degree of Treg expansion will be sufficient to control disease. Alternatively, Tregs can be ex vivo expanded using IL-2 and either anti-CD3/28 antibody-coated beads or anti-CD3 antibody loaded, K562 cell-based artificial antigen-presenting cells APCs (aAPCs) that express the high affinity Fc receptor CD64 and the costimulatory molecule CD86 (termed KT64/86) [43]. As compared to anti-CD3/28 antibody beads, cell-based aAPCs can significantly increase tTreg yield, while dominantly maintaining Foxp3 expression and suppressive function $[43,209]$. Total peripheral blood tTreg expansion induced by successive stimulations with KT64/86 cells was 200 -fold higher compared with anti-CD3/28 beads (25,000 fold vs. 5 million-fold, respectively) [43].

Prolonged ex vivo expansion with repeated stimulations can have a negative impact on Treg Foxp3 expression and suppressive function [101,210,211]. Adding rapamycin to the culture can mitigate these effects, albeit at the cost of cell yield [43]. Peripheral blood tTregs stimulated two times without rapamycin (resulting in $\sim 10000$-fold expansion) or five times with rapamycin (resulting in $~ 10,000,000$-fold expansion) continued to preferentially express the defined Treg "locked in" factors. Importantly, Tregs cultured in rapamycin did not increase exhaustion gene expression even after five stimulations, in contrast to Tregs stimulated two times without rapamycin [212]. To enhance Treg stability during ex vivo expansion, Miyara and colleagues used a combined drug regimen consisting of IL-2, rapamycin, a pan-histone deacetylase inhibitor (vorinostat), and a hyomethylating epigenetic modifier (5-azacitidine). The combination drastically increased Foxp3 stability with an expansion fold that was only $x x$ ? times less than in the presence of IL-2 alone with an overall expansion of 37-fold, considerably lower than other published protocols [213].

With this degree of Treg expansion and since third-party Tregs can effectively suppress acute GVHD in mice, an "off-the-shelf" Treg bank stocked with cryopreserved Treg aliquots is feasible [214]. With current methodologies, Tregs temporarily lose suppressor function upon thawing. While complicating the distribution of Tregs for infusion, function can be restored after overnight IL-2 exposure, supporting the creation of a readily available cell bank [43]. Others have shown that thawing of cryopreserved expanded Tregs followed by restimulation can overcome the detrimental effects of cryopreservation on Treg number and phenotype [215]. In other studies, higher Treg viability and Foxp3 expression were obtained when cells were cryopreserved 1-3 days, but not $>3$ days after last restimulation [216]. The ability to cryopreserve and thaw expanded Tregs will have broad-ranging implications when designing clinical trials.

\subsection{Concurrent Immunosuppressive Drugs}

In allo-HSCT patients, Tregs may rapidly disappear from the peripheral blood, often ascribed to the lack of IL-2 released by T effectors that have been suppressed or use of immunosuppressive drugs, such as calcineurin inhibitors (CNI), that inhibit IL-2 production $[10,217]$. Unlike CNIs, rapamycin preferentially supports Treg expansion due to the differential sensitivity of Teffs vs. Tregs to mTOR inhibition $[218,219]$. As discussed above, rapamycin has been shown to stabilize the suppressor function and gene expression profile of Tregs, both for endogenous and adoptively-transferred Tregs [220]. Therefore, rapamycin is typically favored over CNIs for clinical trials when adoptive Treg therapy is 
added to standard-of-care GVHD prophylaxis. Furthermore, nonhuman primate studies have shown that, rapamycin could promote long-term persistence of adoptively transferred Tregs when combined with IL-2 or OX40L blockade [221]. Other pharmacologic agents such as post-transplant cyclophosphamide, histone deacetylase inhibitors (e.g., vorinostat), hypomethylating agents (e.g., azacitidine), JAK1/2 inhibitors (e.g., Ruxolitinib), and ROCK $1 / 2$ inhibitors (e.g., Belumosudil) have also demonstrated the ability to increase Treg compartment after allo-HSCT [221-228]. Thus, these agents are at least theoretically less likely to negatively impact the efficacy of Treg therapy when given as an adjunct immunomodulatory agent for GVHD.

\subsection{Clinical Efficacy and Adverse Effects}

Initial GVHD therapy studies by Tzonkowski and subsequent phase I/Ib GVHD prevention trials have confirmed the feasibility and safety of adoptive Treg therapy in GVHD (Table 2) $[10,11,36,42,198,199]$. The first acute GVHD prevention clinical studies were reported by two groups $[36,206]$. In our study, UCB was used as the source of tTregs in a phase 1 dose-escalation study [36]. Ex vivo expansion with anti-CD3/antiCD28 antibody-coated beads achieved the targeted Treg dose in $74 \%$ of cultures with retention of suppressive function in all products. Twenty-three patients received a dose of 0.1-30 $\times 10^{5} \mathrm{UCB}$ Treg $/ \mathrm{kg}$ after double UCB transplantation. Adoptive transfer of Tregs in patients receiving mycophenolate and sirolimus/ cyclosporin reduced the incidence of grade II-IV GVHD compared to historical controls (43\% vs. 61\%) [36]. In a second study by our group, tTreg expansion was significantly increased via restimulation with aAPC, resulting in a median expansion of 13,000-fold. In the context of mycophenolate and sirolimus immunosuppression, adoptive transfer of Tregs virtually eliminated grade II-IV acute GVHD, with a cumulative incidence of $9 \%$ at 100 days [10].

In a study by Di Ianni and coworkers, tTregs were freshly isolated from peripheral blood and allowed to become activated and expanded in vivo prior to the infusion of haploidentical T cells. Despite lack of post-transplant immunosuppression, only two of 26 evaluable patients developed $\geq$ grade 2 acute GVHD, and no patient developed chronic GVHD after a median follow-up of 11.2 months [206]. In a more recent study by the same group, 43 patients with high-risk acute leukemia underwent haplo-identical HSCT without post-transplant immunosuppression and received manipulated grafts, containing CD34+ cells (mean $9.7 \times 10^{6} / \mathrm{kg}$ ), Tregs (mean $2.5 \times 10^{6} / \mathrm{kg}$ ), and Tcons (mean $1.1 \times 106 / \mathrm{kg}$ ). Even though $1.1 \times 10^{6} / \mathrm{kg}$ Tcons were infused without any in vivo GVHD prophylaxis, the incidence of grade 2 acute GVHD was $15 \%$, which was similar to the $11 \%$ in historical controls. More importantly, the cumulative incidence of relapse was only $5 \%$, which was significantly lower than in historical controls [11].

The clinical efficacy of adoptive Treg therapy has been less encouraging when used for the treatment rather than the prevention of acute GVHD. The first-in-man clinical trial using ex vivo expanded tTregs for the treatment of GVHD demonstrated significant alleviation of the symptoms in one patient with chronic GVHD, but only transiently improved acute GVHD in a second patient [198]. In another study by Theil et al., adoptive transfer of ex vivo expanded tTregs resulted in clinical response in two out of five patients with refractory chronic GVHD [229].

Large-scale iTreg expansion methods facilitated a first-in-human phase 1 trial of CD4 iTregs that has been completed [43]. A cell dose of $3 \times 10^{8} / \mathrm{kg}$ iTregs (7:1 ratio with Tcons) was safely given as GVHD prophylaxis to HSCT recipients of HLA-matched sibling donors along with cyclosporin and mycophenolate with a reduction, albeit non-significant, in acute GVHD incidence [42]. In tTreg and iTreg trials, neither relapse rates nor the incidence of opportunistic infections have been observed to be increased in small human studies reported to date. Overall, these early phase clinical trials demonstrate that adoptive Treg therapy is a feasible and safe therapeutic approach and may be efficacious especially for GVHD prevention. Larger randomized trials are needed to verify these findings and establish efficacy. 
Table 2. Completed and ongoing clinical trials involving adoptive Treg therapy in GVHD (ClinicalTrials.gov; search date 30 July 2021).

\begin{tabular}{|c|c|c|c|c|c|c|c|c|c|}
\hline Study ID & $\mathrm{Ph}$ & $\begin{array}{l}\text { Enrollment } \\
\text { Actual/Planned }\end{array}$ & HSCT/IST & Indication & Cell Product/Dose & Outcomes & Status & Center & References \\
\hline NCT01634217 & I & $16 / 16$ & $\begin{array}{c}\text { MRD } \\
\text { MMF/Siro, } n=2 \\
\text { MMF/CSA, } n=14\end{array}$ & $\begin{array}{l}\text { GVHD } \\
\text { PPx }\end{array}$ & $\begin{array}{c}\text { Expanded PB CD4 iTregs } \\
\text { Dose-escalation } \\
3 \times 10^{6} / \mathrm{kg}-3 \times 10^{8} / \mathrm{kg}\end{array}$ & $\begin{array}{c}\text { Final Results: } \\
\text { 1st cohort: } 100 \% \text { grade } 3 \\
\text { aGVHD } \\
\text { 2nd cohort: } 20 \% \geq \text { grade } \\
2 \text { aGVHD }\end{array}$ & Completed & $\begin{array}{l}\text { University of } \\
\text { Minnesota, USA }\end{array}$ & [42] \\
\hline NCT02423915 & I & $5 / 5$ & $\begin{array}{c}\text { dUCBT, } n=2 \\
\text { PB MUD, } n=3 \\
\text { MMF/Siro }\end{array}$ & $\begin{array}{l}\text { GVHD } \\
\text { PPx }\end{array}$ & $\begin{array}{c}\text { Fucosylated fresh UCB } \\
\text { CD4 tTreg } \\
1 \times 10^{6} / \mathrm{kg}-1 \times 10^{7} / \mathrm{kg}\end{array}$ & $\begin{array}{c}\text { Final Results: } \\
100 \% \geq \text { grade } 2 \text { aGVHD }\end{array}$ & Completed & MD Anderson, USA & [230] \\
\hline NCT01660607 & $\mathrm{I} / \mathrm{II}$ & $12 / 24$ & $\begin{array}{l}\text { TCD MRD } / \text { MUD } \\
\text { No IST, } n=5 \\
\text { TAC or Siro, } n=7 \\
\text { Remaining, } n=12\end{array}$ & $\begin{array}{l}\text { GVHD } \\
\text { PPx }\end{array}$ & $\begin{array}{c}\text { Fresh CD4 tTregs and Tcons } \\
\text { Dose-escalation and } \\
\text { extension } \\
1 \times 10^{6} / \mathrm{kg}-3 \times 10^{6} / \mathrm{kg} \\
\text { Treg and } \\
1 \times 10^{5} / \mathrm{kg}-3 \times 10^{7} / \mathrm{kg} \\
\text { Tcon } \\
\end{array}$ & $\begin{array}{c}\text { Interim Results: } \\
\text { 1st cohort: } 40 \% \geq \text { grade } 2 \\
\text { aGVHD } \\
\text { 2nd cohort: No GVHD } \\
(\mathrm{n}=7)\end{array}$ & Recruiting & Stanford, USA & [39] \\
\hline NCT01795573 & I & $38 / 48$ & $\begin{array}{c}\text { MRD } \\
\text { IST: unknown }\end{array}$ & $\begin{array}{l}\text { GVHD } \\
\text { PPx }\end{array}$ & $\begin{array}{c}\text { Donor CD4 tTregs } \\
\text { expanded with recipient } \\
\text { DCs } \\
\text { Dose: unknown }\end{array}$ & No results & $\begin{array}{l}\text { Active, not } \\
\text { recruiting }\end{array}$ & $\begin{array}{c}\text { Moffitt Cancer Center, } \\
\text { USA }\end{array}$ & $\mathrm{N} / \mathrm{A}$ \\
\hline $\begin{array}{l}\text { 2012-002685- } \\
12\end{array}$ & I & $9 / 9$ & Not specified & $\begin{array}{l}\text { GVHD } \\
\text { PPx }\end{array}$ & $\begin{array}{c}\text { Fresh CD4 tTreg } \\
\text { Up to } 5 \times 10^{6} / \mathrm{kg} \times \text { once }\end{array}$ & $\begin{array}{c}\text { Final Results: } \\
\text { Safe; not designed for } \\
\text { efficacy }\end{array}$ & Completed & $\begin{array}{l}\text { University Hospital } \\
\text { Regensburg, Germany }\end{array}$ & [231] \\
\hline $01 / 08$ & I & $28 / 28$ & $\begin{array}{l}\text { Haploidentical } \\
\text { Without IST }\end{array}$ & $\begin{array}{l}\text { GVHD } \\
\text { PPx }\end{array}$ & $\begin{array}{c}\text { Fresh PB CD4 tTregs and } \\
\text { Tcons } \\
\text { Dose-escalation } \\
2 \times 10^{6} / \mathrm{kg}-4 \times 10^{6} / \mathrm{kg} \\
\text { Treg and } \\
0.5 \times 10^{6} / \mathrm{kg}-2 \times 10^{6} / \mathrm{kg} \\
\text { Tcon }\end{array}$ & $\begin{array}{c}\text { Final Results: } \\
15 \% \text { developed } \geq \text { grade } 2 \\
\text { aGVHD } \\
5 \% \text { developed relapse }\end{array}$ & Completed & $\begin{array}{l}\text { University of Perugia, } \\
\text { Italy }\end{array}$ & {$[11,206]$} \\
\hline NCT00602693 & I & $11 / 11$ & $\begin{array}{c}\text { dUCBT } \\
\text { MMF/Siro }\end{array}$ & $\begin{array}{l}\text { GVHD } \\
\text { PPx }\end{array}$ & $\begin{array}{c}\text { Expanded UCB CD4 tTreg } \\
\text { Dose-escalation } \\
3 \times 10^{6}-1 \times 10^{8} / \mathrm{kg} \text { Treg }\end{array}$ & $\begin{array}{c}\text { Final Results: } \\
\text { 9\% developed } \geq \text { grade } 2 \\
\text { aGVHD } \\
5 \% \text { developed relapse }\end{array}$ & Completed & $\begin{array}{c}\text { University of } \\
\text { Minnesota, USA }\end{array}$ & [10] \\
\hline
\end{tabular}


Table 2. Cont.

\begin{tabular}{|c|c|c|c|c|c|c|c|c|c|}
\hline Study ID & Ph & $\begin{array}{l}\text { Enrollment } \\
\text { Actual/Planned }\end{array}$ & HSCT/IST & Indication & Cell Product/Dose & Outcomes & Status & Center & References \\
\hline NCT00602693 & I & $23 / 23$ & dUCBT & $\begin{array}{l}\text { GVHD } \\
\text { PPx }\end{array}$ & $\begin{array}{c}\text { Expanded UCB CD4 tTreg } \\
\text { Dose-escalation } \\
0.1 \times 10^{5}-30 \times 10^{5} / \mathrm{kg} \text { Treg }\end{array}$ & $\begin{array}{c}\text { Final Results: } \\
43 \% \geq \text { grade } 2 \text { aGVHD } \\
\text { (vs. } 61 \% \text { in historical } \\
\text { control) }\end{array}$ & Completed & $\begin{array}{c}\text { University of } \\
\text { Minnesota, USA }\end{array}$ & [36] \\
\hline NCT04678401 & I & NA/10 & $\begin{array}{c}\text { Haplo } \\
\text { Without IST }\end{array}$ & $\begin{array}{l}\text { GVHD } \\
\text { PPx }\end{array}$ & $\begin{array}{c}\text { Treg enriched haplo graft } \\
\text { NA: Treg dose }\end{array}$ & No results & Recruiting & $\begin{array}{l}\text { Dana-Farber Cancer } \\
\text { Institute, USA }\end{array}$ & $\mathrm{N} / \mathrm{A}$ \\
\hline NCT01903473 & II & $\begin{array}{l}\text { NA/35 } \\
\text { Treg arm, } \\
n=10 \\
\text { Control, } \\
n=25\end{array}$ & Any & $\begin{array}{c}\text { SR } \\
\text { cGVHD }\end{array}$ & $\begin{array}{c}\text { Fresh PB CD4 tTregs with } \\
\text { sirolimus and low-dose } \\
\text { IL-2 } \\
0.5 \times 10^{6} / \mathrm{kg} \times \text { once }\end{array}$ & No results & Recruiting & $\begin{array}{l}\text { University of Liege, } \\
\text { Belgium }\end{array}$ & $\mathrm{N} / \mathrm{A}$ \\
\hline NCT02385019 & $\mathrm{I} / \mathrm{II}$ & $\mathrm{NA} / 22$ & Any & $\begin{array}{c}\text { SR } \\
\text { cGVHD }\end{array}$ & $\begin{array}{l}\text { Fresh PB CD } 4 \text { tTreg } \\
\text { Dose-escalation and } \\
\text { extension } \\
0.5 \times 10^{6} / \mathrm{kg}-3 \times 10^{6} / \mathrm{kg} \\
\times \text { once }\end{array}$ & No results & Unknown & IMMJLA, Portugal & $\mathrm{N} / \mathrm{A}$ \\
\hline NCT01911039 & I & NA/20 & Any & $\begin{array}{c}\text { SR } \\
\text { cGVHD }\end{array}$ & 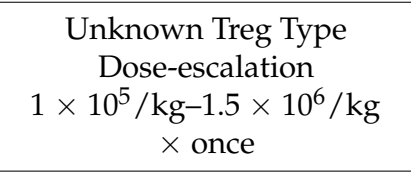 & No results & Unknown & $\begin{array}{l}\text { Stanford University, } \\
\text { USA }\end{array}$ & NA \\
\hline NCT02749084 & $\mathrm{I} / \mathrm{II}$ & $\mathrm{NA} / 20$ & Any & $\begin{array}{c}\text { SR } \\
\text { cGVHD }\end{array}$ & $\begin{array}{c}\text { Multiple donor PB CD4 } \\
\text { tTreg } \\
\text { Dose-escalation } \\
1.7 \times 10^{5} / \mathrm{kg}-6.6 \times 10^{6} / \mathrm{kg} \\
\text { monthly } \times 3\end{array}$ & No results & Recruiting & $\begin{array}{l}\text { Universitaria di } \\
\text { Bologna, Italy }\end{array}$ & NA \\
\hline
\end{tabular}


Table 2. Cont

\begin{tabular}{|c|c|c|c|c|c|c|c|c|c|}
\hline Study ID & Ph & $\begin{array}{l}\text { Enrollment } \\
\text { Actual/Planned }\end{array}$ & HSCT/IST & Indication & Cell Product/Dose & Outcomes & Status & Center & References \\
\hline EK 206082008 & I & $5 / 5$ & Any & $\begin{array}{c}\text { SR } \\
\text { cGVHD }\end{array}$ & $\begin{array}{l}\text { Expanded PB CD4 tTreg } \\
\text { Dose-escalation } \\
5 \times 10^{5} / \mathrm{kg}-4.4 \times 10^{6} / \mathrm{kg} \\
\times \text { once }\end{array}$ & $\begin{array}{c}\text { Final Results: } \\
\text { Clinical response in } 2 \text { pts } \\
\text { Stable disease in } 3 \text { pts }\end{array}$ & Completed & $\begin{array}{l}\text { University Hospital } \\
\text { Carl Gustav Carus, } \\
\text { Germany }\end{array}$ & [229] \\
\hline NCT03683498 & I & $0 / 16$ & Any & $\begin{array}{c}\text { SR } \\
\text { cGVHD }\end{array}$ & $\begin{array}{c}\text { Expanded CD4 tTreg } \\
\text { Dose-escalation } \\
0.5 \times 10^{6} / \mathrm{kg}-2 \times 10^{6} / \mathrm{kg}\end{array}$ & No Results & $\begin{array}{l}\text { Active, not } \\
\text { recruiting }\end{array}$ & FPAGI, Spain & $\mathrm{N} / \mathrm{A}$ \\
\hline NCT01911039 & I & $\mathrm{NA} / 20$ & Any & $\begin{array}{c}\text { SR } \\
\text { cGVHD }\end{array}$ & $\begin{array}{c}\text { Unknown type } \\
\text { Dose-escalation } \\
1 \times 10^{5} / \mathrm{kg}-1.5 \times 10^{6} / \mathrm{kg}\end{array}$ & No Results & Unknown & $\begin{array}{l}\text { Stanford University, } \\
\text { USA }\end{array}$ & $\mathrm{N} / \mathrm{A}$ \\
\hline $\begin{array}{l}\text { NKEBN/458- } \\
310 / 2008\end{array}$ & I & $2 / 2$ & $\begin{array}{c}\text { MRD } \\
\text { Single agent IST }\end{array}$ & $\begin{array}{c}\text { SR } \\
\text { aGVHD } \\
\text { SR } \\
\text { cGVHD }\end{array}$ & $\begin{array}{c}\text { Expanded CD4 tTreg } \\
1 \times 10^{5} / \mathrm{kg} \text { in SR cGVHD } \\
3 \times 10^{6} / \mathrm{kg} \text { in SR aGVHD }\end{array}$ & $\begin{array}{c}\text { Final Results: } \\
\text { Reduced IST in cGVHD } \\
\text { Only transient } \\
\text { improvement in aGVHD }\end{array}$ & Completed & $\begin{array}{l}\text { Medical University of } \\
\text { Gdańsk, Poland }\end{array}$ & [198] \\
\hline NCT01453140 & $\mathrm{I} / \mathrm{II}$ & $3 / 15$ & Any & $\begin{array}{c}\text { SR } \\
\text { aGVHD }\end{array}$ & $\begin{array}{l}\text { Expanded PB CD4 tTreg } \\
\text { with cyclophosphamide } \\
\text { and sirolimus with or } \\
\text { without Azacitidine } \\
\text { Unknown dose }\end{array}$ & No results & Completed & $\begin{array}{c}\text { John Theurer Cancer } \\
\text { Center, USA }\end{array}$ & $\mathrm{N} / \mathrm{A}$ \\
\hline
\end{tabular}




\section{Conclusions and Future Directions}

The past decade has seen substantial advances in our understanding of the Tregs biology and mechanisms of tolerance induction after allo-HSCT. Preclinical and clinical research have established the potential of Treg based therapies as a promising alternative to pharmacologic immunosuppression for GVHD. Although early phase clinical trials have confirmed the feasibility and tolerability of adoptive Treg therapy, few data are available regarding the efficacy and reproducibility of this approach in late stage randomized clinical trials. Treg cell therapy for GVHD has not yet entered clinical practice due to several remaining obstacles including the high dose of polyclonal Tregs required to prevent/treat GVHD, difficulty of ex vivo Treg expansion, and absence of phase III clinical data. It is likely that genetic engineering of Tregs with an enhanced immunosuppressive capacity and an improved ability to expand and exert targeted function will enable their use as a promising therapeutic modality for GVHD. However, more questions remain open regarding potency, specificity, and functional differences of engineered Tregs, as well as the optimal gene delivery techniques (viral or non-viral systems) and manufacturing platforms.

Several start-up companies have recently been funded with the aim of applying genetically engineered Tregs to treat autoimmune and alloimmune conditions [232]. The first CAR-Treg clinical trial has been granted authorization in the UK and the Netherlands (STEADFAST) applying anti-HLA-A2 CD4 Tregs in kidney transplant patients (EUCTR2019-001730-34-NL). The use of gene editing as a tool for generating off-the-shelf CAR-T cells is very promising and can be translated to CAR-Treg therapy. This can be achieved by using CRISPR/Cas9 or transcription-activator-like effector nucleases (TALENs) to knock out the TCR $\alpha$ chain (TRAC) or $\beta 2$ microglobulin of the MHC molecule, to prevent alloreactive T cells from inducing GvHD $[233,234]$. Most CAR Treg studies to date have used the so-called "second-generation" CAR design, which is used in the context of oncology to deliver potent Tcons for tumor eradication. Tregs and Tcons, however, have distinct requirements for suppression/effector function, and thus a future direction is to further optimize CAR design for optimal suppression as opposed to cytotoxicity. Furthermore, Tregs can be modified using new engineering strategies, such as Notch receptors that have an extracellular single-chain antibody and intracellular transcriptional domains that are released and activate expression of target genes [235]. Novel delivery methods such as nanoparticle-based approaches may facilitate precise targeting of cell types, such as Tregs that need to be enhanced in order to restore a tolerizing milieu in target tissues. It should also be noted that other regulatory cell types exist and have shown promise as potential therapeutic tools, including tolerogenic dendritic cells, natural killer cells, regulatory B cells and myeloid-derived suppressive cells $[45,236]$. Human and/or patient organoids, may gain more importance and are promising candidates for examining Treg function in disease models [237]. Furthermore, biomarker studies will be important to define not only the effects of Treg therapy but also the timing and doses of their administration. Overall, the development and production of a successful Treg therapy continues to represent an exciting and challenging endeavor, and one that offers hope for future therapies to be more targeted and efficacious.

Funding: B.R.B. serves on advisory boards for Magenta Therapeutics and BlueRock Theapeutics; receives research funding from BlueRock Therapeutics, Rheos Medicines, Equilibre Pharmaceuticals Corp., and Carisma Therapeutics, Inc; is a co-founder of Tmunity Therapeutics; and receives the following NIH grant support: R37 AI34495, R01 HL147324, R01 HL155114, and R01 HL56067.

Institutional Review Board Statement: Not applicable.

Informed Consent Statement: Not applicable.

Data Availability Statement: Not applicable.

Conflicts of Interest: The authors declare no conflict of interest. 


\section{References}

1. Inamoto, Y.; Martin, P.J.; Storer, B.E.; Mielcarek, M.; Storb, R.F.; Carpenter, P.A. Response endpoints and failure-free survival after initial treatment for acute graft-versus-host disease. Haematologica 2014, 99, 385-391. [CrossRef]

2. Martin, P.J.; Rizzo, J.D.; Wingard, J.R.; Ballen, K.; Curtin, P.T.; Cutler, C.; Litzow, M.R.; Nieto, Y.; Savani, B.N.; Schriber, J.R.; et al. First- and second-line systemic treatment of acute graft-versus-host disease: Recommendations of the American Society of Blood and Marrow Transplantation. Biol. Blood Marrow Transplant. 2012, 18, 1150-1163. [CrossRef]

3. Zeiser, R.; von Bubnoff, N.; Butler, J.; Mohty, M.; Niederwieser, D.; Or, R.; Szer, J.; Wagner, E.M.; Zuckerman, T.; Mahuzier, B.; et al. Ruxolitinib for Glucocorticoid-Refractory Acute Graft-versus-Host Disease. N. Engl. J. Med. 2020, 38, 1800-1810. [CrossRef]

4. Cutler, C.S.; Lee, S.J.; Arai, S.; Rotta, M.; Zoghi, B.; Lazaryan, A.; Ramakrishnan, A.; DeFilipp, Z.; Salhotra, A.; Chai-Ho, W.; et al. Belumosudil for Chronic Graft-versus-Host Disease (cGVHD) After 2 or More Prior Lines of Therapy: The ROCKstar Study. Blood 2021, 136, 45-46. [CrossRef]

5. Miklos, D.; Cutler, C.S.; Arora, M.; Waller, E.K.; Jagasia, M.; Pusic, I.; Flowers, M.E.; Logan, A.C.; Nakamura, R.; Blazar, B.R.; et al. Ibrutinib for chronic graft-versus-host disease after failure of prior therapy. Blood 2017, 130, 2243-2250. [CrossRef] [PubMed]

6. Zeiser, R.; Polverelli, N.; Ram, R.; Hashmi, S.K.; Chakraverty, R.; Middeke, J.M.; Musso, M.; Giebel, S.; Uzay, A.; Langmuir, P.; et al. Ruxolitinib for Glucocorticoid-Refractory Chronic Graft-versus-Host Disease. N. Engl. J. Med. 2021, 385, 228-238. [CrossRef]

7. Arpaia, N.; Green, J.A.; Moltedo, B.; Arvey, A.; Hemmers, S.; Yuan, S.; Treuting, P.M.; Rudensky, A.Y. A Distinct Function of Regulatory T Cells in Tissue Protection. Cell 2015, 162, 1078-1089. [CrossRef]

8. Li, J.; Tan, J.; Martino, M.M.; Lui, K.O. Regulatory T-Cells: Potential Regulator of Tissue Repair and Regeneration. Front. Immunol. 2018, 9, 585. [CrossRef]

9. Zaiss, D.M.; Minutti, C.M.; Knipper, J.A. Immune- and non-immune-mediated roles of regulatory T-cells during wound healing. Immunology 2019, 157, 190-197. [CrossRef] [PubMed]

10. Brunstein, C.G.; Miller, J.S.; McKenna, D.H.; Hippen, K.L.; DeFor, T.E.; Sumstad, D.; Curtsinger, J.; Verneris, M.R.; MacMillan, M.L.; Levine, B.L.; et al. Umbilical cord blood-derived T regulatory cells to prevent GVHD: Kinetics, toxicity profile, and clinical effect. Blood 2016, 127, 1044-1051. [CrossRef]

11. Martelli, M.F.; Di Ianni, M.; Ruggeri, L.; Falzetti, F.; Carotti, A.; Terenzi, A.; Pierini, A.; Massei, M.S.; Amico, L.; Urbani, E.; et al. HLA-haploidentical transplantation with regulatory and conventional T-cell adoptive immunotherapy prevents acute leukemia relapse. Blood 2014, 124, 638-644. [CrossRef]

12. Khattri, R.; Cox, T.; Yasayko, S.-A.; Ramsdell, F. An essential role for Scurfin in $\mathrm{CD} 4^{+} \mathrm{CD} 25^{+}$T regulatory cells. Nat. Immunol. 2003, 4, 337-342. [CrossRef] [PubMed]

13. Fontenot, J.D.; Gavin, M.A.; Rudensky, A.Y. Foxp3 programs the development and function of CD4 ${ }^{+} \mathrm{CD} 25^{+}$regulatory T cells. Nat. Immunol. 2003, 4, 330-336. [CrossRef] [PubMed]

14. Sakaguchi, S.; Sakaguchi, N.; Asano, M.; Itoh, M.; Toda, M. Immunologic self-tolerance maintained by activated T cells expressing IL-2 receptor alpha-chains (CD25). Breakdown of a single mechanism of self-tolerance causes various autoimmune diseases. J. Immunol. 1995, 155, 1151-1164.

15. Baecher-Allan, C.; Brown, J.A.; Freeman, G.J.; Hafler, D.A. CD4 ${ }^{+}$CD25high regulatory cells in human peripheral blood. J. Immunol. 2001, 167, 1245-1253. [CrossRef] [PubMed]

16. Hori, S.; Nomura, T.; Sakaguchi, S. Control of regulatory T cell development by the transcription factor Foxp3. Science 2003, 299, 1057-1061. [CrossRef]

17. Itoh, M.; Takahashi, T.; Sakaguchi, N.; Kuniyasu, Y.; Shimizu, J.; Otsuka, F.; Sakaguchi, S. Thymus and autoimmunity: Production of $\mathrm{CD} 25^{+} \mathrm{CD}^{+}$naturally anergic and suppressive $\mathrm{T}$ cells as a key function of the thymus in maintaining immunologic selftolerance. J. Immunol. 1999, 162, 5317-5326.

18. Abbas, A.K.; Benoist, C.; Bluestone, J.A.; Campbell, D.J.; Ghosh, S.; Hori, S.; Jiang, S.; Kuchroo, V.K.; Mathis, D.; Roncarolo, M.G.; et al. Regulatory T cells: Recommendations to simplify the nomenclature. Nat. Immunol. 2013, 14, 307-308. [CrossRef]

19. Relland, L.M.; Mishra, M.K.; Haribhai, D.; Edwards, B.; Ziegelbauer, J.; Williams, C.B. Affinity-based selection of regulatory T cells occurs independent of agonist-mediated induction of Foxp3 expression. J. Immunol. 2009, 182, 1341-1350. [CrossRef]

20. Relland, L.M.; Williams, J.B.; Relland, G.N.; Haribhai, D.; Ziegelbauer, J.; Yassai, M.; Gorski, J.; Williams, C.B. The TCR repertoires of regulatory and conventional $\mathrm{T}$ cells specific for the same foreign antigen are distinct. J. Immunol. 2012, 189, 3566-3574. [CrossRef]

21. Jordan, M.S.; Boesteanu, A.; Reed, A.J.; Petrone, A.L.; Holenbeck, A.E.; Lerman, M.A.; Naji, A.; Caton, A.J. Thymic selection of $\mathrm{CD}^{+} \mathrm{CD} 25^{+}$regulatory T cells induced by an agonist self-peptide. Nat. Immunol. 2001, 2, 301-306. [CrossRef] [PubMed]

22. Wong, J.; Obst, R.; Correia-Neves, M.; Losyev, G.; Mathis, D.; Benoist, C. Adaptation of TCR repertoires to self-peptides in regulatory and nonregulatory CD4 ${ }^{+}$T cells. J. Immunol. 2007, 178, 7032-7041. [CrossRef] [PubMed]

23. Zhu, J.; Yamane, H.; Paul, W.E. Differentiation of effector CD4 T cell populations (*). Annu. Rev. Immunol. 2010, 28, 445-489. [CrossRef]

24. Wing, J.B.; Tanaka, A.; Sakaguchi, S. Human Foxp3 $3^{+}$Regulatory T Cell Heterogeneity and Function in Autoimmunity and Cancer. Immunity 2019, 50, 302-316. [CrossRef]

25. Sakaguchi, S.; Miyara, M.; Costantino, C.M.; Hafler, D.A. Foxp3 ${ }^{+}$regulatory T cells in the human immune system. Nat. Rev. Immunol. 2010, 10, 490-500. [CrossRef]

26. Shevach, E.M. From vanilla to 28 flavors: Multiple varieties of T regulatory cells. Immunity 2006, 25, 195-201. [CrossRef] [PubMed] 
27. Cretney, E.; Kallies, A.; Nutt, S.L. Differentiation and function of Foxp3(+) effector regulatory T cells. Trends Immunol. 2013, 34, 74-80. [CrossRef] [PubMed]

28. Baron, U.; Floess, S.; Wieczorek, G.; Baumann, K.; Grützkau, A.; Dong, J.; Thiel, A.; Boeld, T.J.; Hoffmann, P.; Edinger, M.; et al. DNA demethylation in the human FOXP3 locus discriminates regulatory T cells from activated FOXP3(+) conventional T cells. Eur. J. Immunol. 2007, 37, 2378-2389. [CrossRef]

29. Janson, P.C.J.; Winerdal, M.E.; Marits, P.; Thörn, M.; Ohlsson, R.; Winqvist, O. FOXP3 promoter demethylation reveals the committed Treg population in humans. PLoS ONE 2008, 3, e1612. [CrossRef]

30. Floess, S.; Freyer, J.; Siewert, C.; Baron, U.; Olek, S.; Polansky, J.; Schlawe, K.; Chang, H.-D.; Bopp, T.; Schmitt, E.; et al. Epigenetic control of the foxp3 locus in regulatory T cells. PLoS Biol. 2007, 5, e38. [CrossRef]

31. Rossetti, M.; Spreafico, R.; Saidin, S.; Chua, C.; Moshref, M.; Leong, J.Y.; Tan, Y.K.; Thumboo, J.; van Loosdregt, J.; Albani, S. Ex vivo-expanded but not in vitro-induced human regulatory $\mathrm{T}$ cells are candidates for cell therapy in autoimmune diseases thanks to stable demethylation of the FOXP3 regulatory T cell-specific demethylated region. J. Immunol. 2015, 194, 113-124. [CrossRef]

32. Zhou, X.; Bailey-Bucktrout, S.L.; Jeker, L.T.; Penaranda, C.; Martínez-Llordella, M.; Ashby, M.; Nakayama, M.; Rosenthal, W.; Bluestone, J.A. Instability of the transcription factor Foxp3 leads to the generation of pathogenic memory T cells in vivo. Nat. Immunol. 2009, 10, 1000-1007. [CrossRef]

33. Sakaguchi, S.; Vignali, D.A.A.; Rudensky, A.Y.; Niec, R.E.; Waldmann, H. The plasticity and stability of regulatory T cells. Nat. Rev. Immunol. 2013, 13, 461-467. [CrossRef] [PubMed]

34. Nie, H.; Zheng, Y.; Li, R.; Guo, T.B.; He, D.; Fang, L.; Liu, X.; Xiao, L.; Chen, X.; Wan, B.; et al. Phosphorylation of FOXP3 controls regulatory $\mathrm{T}$ cell function and is inhibited by TNF- $\alpha$ in rheumatoid arthritis. Nat. Med. 2013, 19, 322-328. [CrossRef] [PubMed]

35. Rubtsov, Y.P.; Niec, R.E.; Josefowicz, S.; Li, L.; Darce, J.; Mathis, D.; Benoist, C.; Rudensky, A.Y. Stability of the regulatory T cell lineage in vivo. Science 2010, 329, 1667-1671. [CrossRef] [PubMed]

36. Brunstein, C.G.; Miller, J.S.; Cao, Q.; McKenna, D.H.; Hippen, K.L.; Curtsinger, J.; Defor, T.; Levine, B.L.; June, C.H.; Rubinstein, P.; et al. Infusion of ex vivo expanded $\mathrm{T}$ regulatory cells in adults transplanted with umbilical cord blood: Safety profile and detection kinetics. Blood 2011, 117, 1061-1070. [CrossRef] [PubMed]

37. Hulspas, R.; Villa-Komaroff, L.; Koksal, E.; Etienne, K.; Rogers, P.; Tuttle, M.; Korsgren, O.; Sharpe, J.C.; Berglund, D. Purification of regulatory $\mathrm{T}$ cells with the use of a fully enclosed high-speed microfluidic system. Cytotherapy 2014, 16, 1384-1389. [CrossRef] [PubMed]

38. McDonald-Hyman, C.; Muller, J.T.; Loschi, M.; Thangavelu, G.; Saha, A.; Kumari, S.; Reichenbach, D.K.; Smith, M.J.; Zhang, G.; Koehn, B.H.; et al. The vimentin intermediate filament network restrains regulatory $\mathrm{T}$ cell suppression of graft-versus-host disease. J. Clin. Investig. 2018, 128, 4604-4621. [CrossRef] [PubMed]

39. Meyer, E.H.; Laport, G.; Xie, B.J.; MacDonald, K.; Heydari, K.; Sahaf, B.; Tang, S.-W.; Baker, J.; Armstrong, R.; Tate, K.; et al. Transplantation of donor grafts with defined ratio of conventional and regulatory T cells in HLA-matched recipients. JCI Insight 2019, 4, 857-870. [CrossRef]

40. Edinger, M.; Hoffmann, P.; Ermann, J.; Drago, K.; Fathman, C.G.; Strober, S.; Negrin, R.S. CD4 ${ }^{+}$CD25 ${ }^{+}$regulatory T cells preserve graft-versus-tumor activity while inhibiting graft-versus-host disease after bone marrow transplantation. Nat. Med. 2003, 9, 1144-1150. [CrossRef]

41. Trenado, A.; Charlotte, F.; Fisson, S.; Yagello, M.; Klatzmann, D.; Salomon, B.L.; Cohen, J.L. Recipient-type specific CD4 ${ }^{+}$CD25 ${ }^{+}$ regulatory $\mathrm{T}$ cells favor immune reconstitution and control graft-versus-host disease while maintaining graft-versus-leukemia. $J$. Clin. Investig. 2003, 112, 1688-1696. [CrossRef]

42. MacMillan, M.L.; Hippen, K.L.; McKenna, D.H.; Kadidlo, D.; Sumstad, D.; Defor, T.E.; Brunstein, C.G.; Holtan, S.G.; Miller, J.S.; Warlick, E.D.; et al. First-in-human phase 1 trial of induced regulatory T cells for graft-versus-host disease prophylaxis in HLA-matched siblings. Blood Adv. 2021, 5, 1425-1436. [CrossRef]

43. Hippen, K.L.; Merkel, S.C.; Schirm, D.K.; Nelson, C.; Tennis, N.C.; Riley, J.L.; June, C.H.; Miller, J.S.; Wagner, J.E.; Blazar, B.R. Generation and large-scale expansion of human inducible regulatory T cells that suppress graft-versus-host disease. Am. J. Transplant. 2011, 11, 1148-1157. [CrossRef]

44. Thangavelu, G.; Blazar, B.R. Achievement of Tolerance Induction to Prevent Acute Graft-vs.-Host Disease. Front. Immunol. 2019, 10, 309. [CrossRef]

45. Blazar, B.R.; MacDonald, K.P.A.; Hill, G.R. Immune regulatory cell infusion for graft-versus-host disease prevention and therapy. Blood 2018, 131, 2651-2660. [CrossRef] [PubMed]

46. Bertaina, A.; Roncarolo, M.G. Graft Engineering and Adoptive Immunotherapy: New Approaches to Promote Immune Tolerance After Hematopoietic Stem Cell Transplantation. Front. Immunol. 2019, 10, 1342. [CrossRef] [PubMed]

47. Locafaro, G.; Andolfi, G.; Russo, F.; Cesana, L.; Spinelli, A.; Camisa, B.; Ciceri, F.; Lombardo, A.; Bondanza, A.; Roncarolo, M.G.; et al. IL-10-Engineered Human CD4 ${ }^{+}$Tr1 Cells Eliminate Myeloid Leukemia in an HLA Class I-Dependent Mechanism. Mol. Ther. 2017, 25, 2254-2269. [CrossRef]

48. Flynn, R.; Du, J.; Veenstra, R.G.; Reichenbach, D.K.; Panoskaltsis-Mortari, A.; Taylor, P.A.; Freeman, G.J.; Serody, J.S.; Murphy, W.J.; Munn, D.H.; et al. Increased T follicular helper cells and germinal center B cells are required for cGVHD and bronchiolitis obliterans. Blood 2014, 123, 3988-3998. [CrossRef] 
49. McDonald-Hyman, C.; Flynn, R.; Panoskaltsis-Mortari, A.; Peterson, N.; MacDonald, K.P.A.; Hill, G.R.; Luznik, L.; Serody, J.S.; Murphy, W.J.; Maillard, I.; et al. Therapeutic regulatory T-cell adoptive transfer ameliorates established murine chronic GVHD in a CXCR5-dependent manner. Blood 2016, 128, 1013-1017. [CrossRef]

50. Heinrichs, J.; Li, J.; Nguyen, H.; Wu, Y.; Bastian, D.; Daethanasanmak, A.; Sofi, M.-H.; Schutt, S.; Liu, C.; Jin, J.; et al. CD8(+) Tregs promote GVHD prevention and overcome the impaired GVL effect mediated by CD4(+) Tregs in mice. Oncoimmunology 2016, 5, e1146842. [CrossRef]

51. Bennett, C.L.; Christie, J.; Ramsdell, F.; Brunkow, M.E.; Ferguson, P.J.; Whitesell, L.; Kelly, T.E.; Saulsbury, F.T.; Chance, P.F.; Ochs, H.D. The immune dysregulation, polyendocrinopathy, enteropathy, X-linked syndrome (IPEX) is caused by mutations of FOXP3. Nat. Genet. 2001, 27, 20-21. [CrossRef]

52. Bluestone, J.A.; Tang, Q. Treg cells-the next frontier of cell therapy. Science 2018, 362, 154-155. [CrossRef]

53. Taylor, P.A.; Noelle, R.J.; Blazar, B.R. CD4(+)CD25(+) immune regulatory cells are required for induction of tolerance to alloantigen via costimulatory blockade. J. Exp. Med. 2001, 193, 1311-1318. [CrossRef]

54. Cohen, J.L.; Trenado, A.; Vasey, D.; Klatzmann, D.; Salomon, B.L. CD4(+)CD25(+) immunoregulatory T Cells: New therapeutics for graft-versus-host disease. J. Exp. Med. 2002, 196, 401-406. [CrossRef]

55. Hoffmann, P.; Ermann, J.; Edinger, M.; Fathman, C.G.; Strober, S. Donor-type CD4(+)CD25(+) regulatory T cells suppress lethal acute graft-versus-host disease after allogeneic bone marrow transplantation. J. Exp. Med. 2002, 196, 389-399. [CrossRef] [PubMed]

56. Taylor, P.A.; Lees, C.J.; Blazar, B.R. The infusion of ex vivo activated and expanded CD $4^{+} \mathrm{CD} 25^{+}$immune regulatory cells inhibits graft-versus-host disease lethality. Blood 2002, 99, 3493-3499. [CrossRef] [PubMed]

57. Walsh, P.T.; Taylor, D.K.; Turka, L.A. Tregs and transplantation tolerance. J. Clin. Investig. 2004, 114, 1398-1403. [CrossRef] [PubMed]

58. Mathew, J.M.; H-Voss, J.; LeFever, A.; Konieczna, I.; Stratton, C.; He, J.; Huang, X.; Gallon, L.; Skaro, A.; Ansari, M.J.; et al. A Phase I Clinical Trial with Ex Vivo Expanded Recipient Regulatory T cells in Living Donor Kidney Transplants. Sci. Rep. 2018, 8, 7428. [CrossRef]

59. Junius, S.; Mavrogiannis, A.V.; Lemaitre, P.; Gerbaux, M.; Staels, F.; Malviya, V.; Burton, O.; Gergelits, V.; Singh, K.; Tito Tadeo, R.Y.; et al. Unstable regulatory T cells, enriched for naïve and Nrp1neg cells, are purged after fate challenge. Sci. Immunol. 2021, 6, 4723. [CrossRef]

60. Lu, L.; Zhou, X.; Wang, J.; Zheng, S.G.; Horwitz, D.A. Characterization of protective human CD4CD25 FOXP3 regulatory T cells generated with IL-2, TGF- $\beta$ and retinoic acid. PLoS ONE 2010, 5, e15150. [CrossRef]

61. Xu, L.; Kitani, A.; Fuss, I.; Strober, W. Cutting edge: Regulatory T cells induce CD $4^{+} \mathrm{CD} 25^{-}$Foxp3 ${ }^{-}$T cells or are self-induced to become Th17 cells in the absence of exogenous TGF-beta. J. Immunol. 2007, 178, 6725-6729. [CrossRef] [PubMed]

62. Zheng, S.G.; Wang, J.; Horwitz, D.A. Cutting edge: Foxp $3^{+} \mathrm{CD} 4^{+} \mathrm{CD} 25^{+}$regulatory T cells induced by IL-2 and TGF-beta are resistant to Th17 conversion by IL-6. J. Immunol. 2008, 180, 7112-7116. [CrossRef] [PubMed]

63. Zhou, X.; Kong, N.; Wang, J.; Fan, H.; Zou, H.; Horwitz, D.; Brand, D.; Liu, Z.; Zheng, S.G. Cutting Edge: All- Trans Retinoic Acid Sustains the Stability and Function of Natural Regulatory T Cells in an Inflammatory Milieu. J. Immunol. 2010, 185, 2675-2679. [CrossRef]

64. Wan, Y.Y.; Flavell, R.A. Regulatory T-cell functions are subverted and converted owing to attenuated Foxp3 expression. Nature 2007, 445, 766-770. [CrossRef]

65. Levine, A.G.; Mendoza, A.; Hemmers, S.; Moltedo, B.; Niec, R.E.; Schizas, M.; Hoyos, B.E.; Putintseva, E.V.; Chaudhry, A.; Dikiy, S.; et al. Corrigendum: Stability and function of regulatory T cells expressing the transcription factor T-bet. Nature 2017, 550, 142. [CrossRef]

66. Hill, J.A.; Hall, J.A.; Sun, C.-M.; Cai, Q.; Ghyselinck, N.; Chambon, P.; Belkaid, Y.; Mathis, D.; Benoist, C. Retinoic acid enhances Foxp3 induction indirectly by relieving inhibition from CD4 ${ }^{+} \mathrm{CD} 44$ hi Cells. Immunity 2008, 29, 758-770. [CrossRef]

67. Mucida, D.; Park, Y.; Kim, G.; Turovskaya, O.; Scott, I.; Kronenberg, M.; Cheroutre, H. Reciprocal TH17 and regulatory T cell differentiation mediated by retinoic acid. Science 2007, 317, 256-260. [CrossRef]

68. Haribhai, D.; Williams, J.B.; Jia, S.; Nickerson, D.; Schmitt, E.G.; Edwards, B.; Ziegelbauer, J.; Yassai, M.; Li, S.-H.; Relland, L.M.; et al. A requisite role for induced regulatory $\mathrm{T}$ cells in tolerance based on expanding antigen receptor diversity. Immunity 2011, 35, 109-122. [CrossRef]

69. Haribhai, D.; Lin, W.; Edwards, B.; Ziegelbauer, J.; Salzman, N.H.; Carlson, M.R.; Li, S.-H.; Simpson, P.M.; Chatila, T.A.; Williams, C.B. A central role for induced regulatory T cells in tolerance induction in experimental colitis. J. Immunol. 2009, 182, 3461-3468. [CrossRef]

70. Chen, W.; Jin, W.; Hardegen, N.; Lei, K.-J.; Li, L.; Marinos, N.; McGrady, G.; Wahl, S.M. Conversion of peripheral CD4 ${ }^{+}$CD25 ${ }^{-}$ naive $\mathrm{T}$ cells to $\mathrm{CD} 4{ }^{+} \mathrm{CD} 25^{+}$regulatory $\mathrm{T}$ cells by TGF-beta induction of transcription factor Foxp3. J. Exp. Med. 2003, 198, 1875-1886. [CrossRef]

71. De Zoeten, E.F.; Wang, L.; Butler, K.; Beier, U.H.; Akimova, T.; Sai, H.; Bradner, J.E.; Mazitschek, R.; Kozikowski, A.P.; Matthias, P.; et al. Histone deacetylase 6 and heat shock protein 90 control the functions of Foxp3(+) T-regulatory cells. Mol. Cell. Biol. 2011, 31, 2066-2078. [CrossRef]

72. Kim, H.-P.; Leonard, W.J. CREB/ATF-dependent T cell receptor-induced FoxP3 gene expression: A role for DNA methylation. J. Exp. Med. 2007, 204, 1543-1551. [CrossRef] [PubMed] 
73. Polansky, J.K.; Kretschmer, K.; Freyer, J.; Floess, S.; Garbe, A.; Baron, U.; Olek, S.; Hamann, A.; von Boehmer, H.; Huehn, J. DNA methylation controls Foxp3 gene expression. Eur. J. Immunol. 2008, 38, 1654-1663. [CrossRef] [PubMed]

74. Sasidharan Nair, V.; Song, M.H.; Oh, K.I. Vitamin C Facilitates Demethylation of the Foxp3 Enhancer in a Tet-Dependent Manner. J. Immunol. 2016, 196, 2119-2131. [CrossRef] [PubMed]

75. Yue, X.; Trifari, S.; Äijö, T.; Tsagaratou, A.; Pastor, W.A.; Zepeda-Martínez, J.A.; Lio, C.W.J.; Li, X.; Huang, Y.; Vijayanand, P.; et al Control of Foxp3 stability through modulation of TET activity. J. Exp. Med. 2016, 213, 377-397. [CrossRef] [PubMed]

76. Zhang, P.; Tey, S.-K.; Koyama, M.; Kuns, R.D.; Olver, S.D.; Lineburg, K.E.; Lor, M.; Teal, B.E.; Raffelt, N.C.; Raju, J.; et al. Induced regulatory T cells promote tolerance when stabilized by rapamycin and IL-2 in vivo. J. Immunol. 2013, 191, 5291-5303. [CrossRef]

77. Beres, A.J.; Haribhai, D.; Chadwick, A.C.; Gonyo, P.J.; Williams, C.B.; Drobyski, W.R. CD8+ Foxp3 ${ }^{+}$regulatory T cells are induced during graft-versus-host disease and mitigate disease severity. J. Immunol. 2012, 189, 464-474. [CrossRef]

78. Bézie, S.; Anegon, I.; Guillonneau, C. Advances on CD8 ${ }^{+}$Treg Cells and Their Potential in Transplantation. Transplantation 2018, 102, 1467-1478. [CrossRef]

79. Dai, Z.; Zhang, S.; Xie, Q.; Wu, S.; Su, J.; Li, S.; Xu, Y.; Li, X.C. Natural CD8 ${ }^{+} \mathrm{CD} 122^{+} \mathrm{T}$ cells are more potent in suppression of allograft rejection than $\mathrm{CD} 4{ }^{+} \mathrm{CD} 25^{+}$regulatory T cells. Am. J. Transplant 2014, 14, 39-48. [CrossRef]

80. Endharti, A.T.; Rifa'I, M.; Shi, Z.; Fukuoka, Y.; Nakahara, Y.; Kawamoto, Y.; Takeda, K.; Isobe, K.-I.; Suzuki, H. Cutting edge: $\mathrm{CD}^{+} \mathrm{CD} 122^{+}$regulatory T cells produce IL-10 to suppress IFN-gamma production and proliferation of CD8 ${ }^{+} \mathrm{T}$ cells. J. Immunol. 2005, 175, 7093-7097. [CrossRef]

81. Kosiewicz, M.M.; Alard, P.; Liang, S.; Clark, S.L. Mechanisms of tolerance induced by transforming growth factor-beta-treated antigen-presenting cells: CD8 regulatory $\mathrm{T}$ cells inhibit the effector phase of the immune response in primed mice through a mechanism involving Fas ligand. Int. Immunol. 2004, 16, 697-706. [CrossRef] [PubMed]

82. Zhang, X.; Ouyang, X.; Xu, Z.; Chen, J.; Huang, Q.; Liu, Y.; Xu, T.; Wang, J.; Olsen, N.; Xu, A.; et al. CD8 ${ }^{+}$CD103 ${ }^{+}$iTregs Inhibit Chronic Graft-versus-Host Disease with Lupus Nephritis by the Increased Expression of CD39. Mol. Ther. 2019, 27, 1963-1973. [CrossRef]

83. Zheng, J.; Liu, Y.; Liu, Y.; Liu, M.; Xiang, Z.; Lam, K.-T.; Lewis, D.B.; Lau, Y.-L.; Tu, W. Human CD8 ${ }^{+}$regulatory T cells inhibit GVHD and preserve general immunity in humanized mice. Sci. Transl. Med. 2013, 5, 168. [CrossRef] [PubMed]

84. Iamsawat, S.; Tian, L.; Daenthanasanmak, A.; Wu, Y.; Nguyen, H.D.; Bastian, D.; Yu, X.-Z. Vitamin C stabilizes CD8 ${ }^{+}$iTregs and enhances their therapeutic potential in controlling murine GVHD and leukemia relapse. Blood Adv. 2019, 3, 4187-4201. [CrossRef] [PubMed]

85. Betts, B.C.; Veerapathran, A.; Pidala, J.; Yu, X.-Z.; Anasetti, C. STAT5 polarization promotes iTregs and suppresses human T-cell alloresponses while preserving CTL capacity. J. Leukoc. Biol. 2014, 95, 205-213. [CrossRef]

86. Iamsawat, S.; Daenthanasanmak, A.; Voss, J.H.; Nguyen, H.; Bastian, D.; Liu, C.; Yu, X.-Z. Stabilization of Foxp3 by Targeting JAK2 Enhances Efficacy of CD8 Induced Regulatory T Cells in the Prevention of Graft-versus-Host Disease. J. Immunol. 2018, 201, 2812-2823. [CrossRef] [PubMed]

87. Semple, K.; Yu, Y.; Wang, D.; Anasetti, C.; Yu, X.-Z. Efficient and selective prevention of GVHD by antigen-specific induced Tregs via linked-suppression in mice. Biol. Blood Marrow Transplant. 2011, 17, 309-318. [CrossRef]

88. Gagliani, N.; Magnani, C.F.; Huber, S.; Gianolini, M.E.; Pala, M.; Licona-Limon, P.; Guo, B.; Herbert, D.R.; Bulfone, A.; Trentini, F.; et al. Coexpression of CD49b and LAG-3 identifies human and mouse T regulatory type 1 cells. Nat. Med. 2013, 19, 739-746. [CrossRef]

89. Gregori, S.; Goudy, K.S.; Roncarolo, M.G. The cellular and molecular mechanisms of immuno-suppression by human type 1 regulatory T cells. Front. Immunol. 2012, 3, 30. [CrossRef]

90. Roncarolo, M.G.; Gregori, S.; Bacchetta, R.; Battaglia, M. Tr1 cells and the counter-regulation of immunity: Natural mechanisms and therapeutic applications. Curr. Top. Microbiol. Immunol. 2014, 380, 39-68. [CrossRef]

91. Zhang, P.; Lee, J.S.; Gartlan, K.H.; Schuster, I.S.; Comerford, I.; Varelias, A.; Ullah, M.A.; Vuckovic, S.; Koyama, M.; Kuns, R.D.; et al. Eomesodermin promotes the development of type 1 regulatory T (TR1) cells. Sci. Immunol. 2017, 2, 10. [CrossRef]

92. Bacchetta, R.; Bigler, M.; Touraine, J.L.; Parkman, R.; Tovo, P.A.; Abrams, J.; de Waal Malefyt, R.; de Vries, J.E.; Roncarolo, M.G. High levels of interleukin 10 production in vivo are associated with tolerance in SCID patients transplanted with HLA mismatched hematopoietic stem cells. J. Exp. Med. 1994, 179, 493-502. [CrossRef]

93. Akdis, M.; Verhagen, J.; Taylor, A.; Karamloo, F.; Karagiannidis, C.; Crameri, R.; Thunberg, S.; Deniz, G.; Valenta, R.; Fiebig, H.; et al. Immune responses in healthy and allergic individuals are characterized by a fine balance between allergen-specific $\mathrm{T}$ regulatory 1 and T helper 2 cells. J. Exp. Med. 2004, 199, 1567-1575. [CrossRef]

94. Magnani, C.F.; Alberigo, G.; Bacchetta, R.; Serafini, G.; Andreani, M.; Roncarolo, M.G.; Gregori, S. Killing of myeloid APCs via HLA class I, CD2 and CD226 defines a novel mechanism of suppression by human Tr1 cells. Eur. J. Immunol. 2011, 41, 1652-1662. [CrossRef]

95. Barrat, F.J.; Cua, D.J.; Boonstra, A.; Richards, D.F.; Crain, C.; Savelkoul, H.F.; de Waal-Malefyt, R.; Coffman, R.L.; Hawrylowicz, C.M.; O'Garra, A. In vitro generation of interleukin 10-producing regulatory CD4(+) T cells is induced by immunosuppressive drugs and inhibited by T helper type 1 (Th1)- and Th2-inducing cytokines. J. Exp. Med. 2002, 195, 603-616. [CrossRef] [PubMed]

96. Battaglia, M.; Gregori, S.; Bacchetta, R.; Roncarolo, M.-G. Tr1 cells: From discovery to their clinical application. Semin. Immunol. 2006, 18, 120-127. [CrossRef] 
97. Gregori, S.; Tomasoni, D.; Pacciani, V.; Scirpoli, M.; Battaglia, M.; Magnani, C.F.; Hauben, E.; Roncarolo, M.-G. Differentiation of type $1 \mathrm{~T}$ regulatory cells (Tr1) by tolerogenic DC-10 requires the IL-10-dependent ILT4/HLA-G pathway. Blood 2010, 116, 935-944. [CrossRef]

98. Levings, M.K.; Sangregorio, R.; Galbiati, F.; Squadrone, S.; de Waal Malefyt, R.; Roncarolo, M.G. IFN-alpha and IL-10 induce the differentiation of human type $1 \mathrm{~T}$ regulatory cells. J. Immunol. 2001, 166, 5530-5539. [CrossRef] [PubMed]

99. Jeon, Y.-W.; Lim, J.-Y.; Im, K.-I.; Kim, N.; Nam, Y.-S.; Song, Y.-J.; Cho, S.-G. Enhancement of Graft-Versus-Host Disease Control Efficacy by Adoptive Transfer of Type 1 Regulatory T Cells in Bone Marrow Transplant Model. Stem Cells Dev. 2019, 28, 129-140. [CrossRef] [PubMed]

100. Bacchetta, R.; Lucarelli, B.; Sartirana, C.; Gregori, S.; Lupo Stanghellini, M.T.; Miqueu, P.; Tomiuk, S.; Hernandez-Fuentes, M.; Gianolini, M.E.; Greco, R.; et al. Immunological Outcome in Haploidentical-HSC Transplanted Patients Treated with IL-10-Anergized Donor T Cells. Front. Immunol. 2014, 5, 16. [CrossRef]

101. Sayitoglu, E.C.; Freeborn, R.A.; Roncarolo, M.G. The Yin and Yang of Type 1 Regulatory T Cells: From Discovery to Clinical Application. Front. Immunol. 2021, 12, 693105. [CrossRef]

102. Linterman, M.A.; Pierson, W.; Lee, S.K.; Kallies, A.; Kawamoto, S.; Rayner, T.F.; Srivastava, M.; Divekar, D.P.; Beaton, L.; Hogan, J.J.; et al. Foxp3 ${ }^{+}$follicular regulatory T cells control the germinal center response. Nat. Med. 2011, 17, 975-982. [CrossRef]

103. Sage, P.T.; Ron-Harel, N.; Juneja, V.R.; Sen, D.R.; Maleri, S.; Sungnak, W.; Kuchroo, V.K.; Haining, W.N.; Chevrier, N.; Haigis, M.; et al. Suppression by TFR cells leads to durable and selective inhibition of B cell effector function. Nat. Immunol. 2016, 17, 1436-1446. [CrossRef]

104. Chung, Y.; Tanaka, S.; Chu, F.; Nurieva, R.I.; Martinez, G.J.; Rawal, S.; Wang, Y.-H.; Lim, H.; Reynolds, J.M.; Zhou, X.; et al. Follicular regulatory $\mathrm{T}$ cells expressing Foxp3 and Bcl-6 suppress germinal center reactions. Nat. Med. 2011, 17, 983-988. [CrossRef]

105. Sage, P.T.; Alvarez, D.; Godec, J.; von Andrian, U.H.; Sharpe, A.H. Circulating T follicular regulatory and helper cells have memory-like properties. J. Clin. Investig. 2014, 124, 5191-5204. [CrossRef]

106. Wollenberg, I.; Agua-Doce, A.; Hernández, A.; Almeida, C.; Oliveira, V.G.; Faro, J.; Graca, L. Regulation of the germinal center reaction by Foxp $3^{+}$follicular regulatory T cells. J. Immunol. 2011, 187, 4553-4560. [CrossRef] [PubMed]

107. Forcade, E.; Kim, H.T.; Cutler, C.; Wang, K.; Alho, A.C.; Nikiforow, S.; Ho, V.T.; Koreth, J.; Armand, P.; Alyea, E.P.; et al. Circulating $\mathrm{T}$ follicular helper cells with increased function during chronic graft-versus-host disease. Blood 2016, 127, 2489-2497. [CrossRef] [PubMed]

108. Koreth, J.; Matsuoka, K.; Kim, H.T.; McDonough, S.M.; Bindra, B.; Alyea, E.P.; Armand, P.; Cutler, C.; Ho, V.T.; Treister, N.S.; et al. Interleukin-2 and regulatory T cells in graft-versus-host disease. N. Engl. J. Med. 2011, 365, 2055-2066. [CrossRef]

109. Matsuoka, K.; Koreth, J.; Kim, H.T.; Bascug, G.; McDonough, S.; Kawano, Y.; Murase, K.; Cutler, C.; Ho, V.T.; Alyea, E.P.; et al. Low-dose interleukin-2 therapy restores regulatory $\mathrm{T}$ cell homeostasis in patients with chronic graft-versus-host disease. Sci. Transl. Med. 2013, 5, 179. [CrossRef] [PubMed]

110. Wing, J.B.; Kitagawa, Y.; Locci, M.; Hume, H.; Tay, C.; Morita, T.; Kidani, Y.; Matsuda, K.; Inoue, T.; Kurosaki, T.; et al. A distinct subpopulation of $\mathrm{CD} 25^{-}$T-follicular regulatory cells localizes in the germinal centers. Proc. Natl. Acad. Sci. USA 2017, 114, E6400-E6409. [CrossRef]

111. Botta, D.; Fuller, M.J.; Marquez-Lago, T.T.; Bachus, H.; Bradley, J.E.; Weinmann, A.S.; Zajac, A.J.; Randall, T.D.; Lund, F.E.; León, B.; et al. Dynamic regulation of $\mathrm{T}$ follicular regulatory cell responses by interleukin 2 during influenza infection. Nat. Immunol. 2017, 18, 1249-1260. [CrossRef]

112. Ritvo, P.-G.G.; Churlaud, G.; Quiniou, V.; Florez, L.; Brimaud, F.; Fourcade, G.; Mariotti-Ferrandiz, E.; Klatzmann, D. Tfr cells lack IL-2R $\alpha$ but express decoy IL-1R2 and IL-1Ra and suppress the IL-1-dependent activation of Tfh cells. Sci. Immunol. $2017,2,15$. [CrossRef]

113. Kim, Y.U.; Kim, B.-S.; Lim, H.; Wetsel, R.A.; Chung, Y. Enforced Expression of CXCR5 Drives T Follicular Regulatory-Like Features in Foxp3 ${ }^{+}$T Cells. Biomol. Ther. 2017, 25, 130-139. [CrossRef]

114. Sagoo, P.; Ali, N.; Garg, G.; Nestle, F.O.; Lechler, R.I.; Lombardi, G. Human regulatory T cells with alloantigen specificity are more potent inhibitors of alloimmune skin graft damage than polyclonal regulatory T cells. Sci. Transl. Med. 2011, 3, 83. [CrossRef] [PubMed]

115. Lee, L.M.; Zhang, H.; Lee, K.; Liang, H.; Merleev, A.; Vincenti, F.; Maverakis, E.; Thomson, A.W.; Tang, Q. A Comparison of Ex Vivo Expanded Human Regulatory T Cells Using Allogeneic Stimulated B Cells or Monocyte-Derived Dendritic Cells. Front. Immunol. 2021, 12, 1-13. [CrossRef]

116. Veerapathran, A.; Pidala, J.; Beato, F.; Yu, X.-Z.; Anasetti, C. Ex vivo expansion of human Tregs specific for alloantigens presented directly or indirectly. Blood 2011, 118, 5671-5680. [CrossRef] [PubMed]

117. Picarda, E.; Bézie, S.; Usero, L.; Ossart, J.; Besnard, M.; Halim, H.; Echasserieau, K.; Usal, C.; Rossjohn, J.; Bernardeau, K.; et al. Cross-Reactive Donor-Specific CD8 ${ }^{+}$Tregs Efficiently Prevent Transplant Rejection. Cell Rep. 2019, 29, 4245-4255.e6. [CrossRef] [PubMed]

118. Noyan, F.; Zimmermann, K.; Hardtke-Wolenski, M.; Knoefel, A.; Schulde, E.; Geffers, R.; Hust, M.; Huehn, J.; Galla, M.; Morgan, M.; et al. Prevention of Allograft Rejection by Use of Regulatory T Cells With an MHC-Specific Chimeric Antigen Receptor. Am. J. Transplant. 2017, 17, 917-930. [CrossRef] [PubMed] 
119. MacDonald, K.G.; Hoeppli, R.E.; Huang, Q.; Gillies, J.; Luciani, D.S.; Orban, P.C.; Broady, R.; Levings, M.K. Alloantigen-specific regulatory $\mathrm{T}$ cells generated with a chimeric antigen receptor. J. Clin. Investig. 2016, 126, 1413-1424. [CrossRef] [PubMed]

120. Hull, C.M.; Nickolay, L.E.; Estorninho, M.; Richardson, M.W.; Riley, J.L.; Peakman, M.; Maher, J.; Tree, T.I.M.M. Generation of human islet-specific regulatory T cells by TCR gene transfer. J. Autoimmun. 2017, 79, 63-73. [CrossRef]

121. Kim, Y.C.; Zhang, A.-H.; Su, Y.; Rieder, S.A.; Rossi, R.J.; Ettinger, R.A.; Pratt, K.P.; Shevach, E.M.; Scott, D.W. Engineered antigenspecific human regulatory T cells: Immunosuppression of FVIII-specific T- and B-cell responses. Blood 2015, 125, 1107-1115. [CrossRef]

122. Kim, Y.C.; Zhang, A.-H.; Yoon, J.; Culp, W.E.; Lees, J.R.; Wucherpfennig, K.W.; Scott, D.W. Engineered MBP-specific human Tregs ameliorate MOG-induced EAE through IL-2-triggered inhibition of effector T cells. J. Autoimmun. 2018, 92, 77-86. [CrossRef]

123. Tsang, J.Y.S.; Tanriver, Y.; Jiang, S.; Xue, S.A.; Ratnasothy, K.; Chen, D.; Stauss, H.J.; Bucy, R.P.; Lombardi, G.; Lechler, R. Conferring indirect allospecificity on $\mathrm{CD} 4{ }^{+} \mathrm{CD} 25^{+}$Tregs by TCR gene transfer favors transplantation tolerance in mice. J. Clin. Investig. 2008, 118, 3619-3628. [CrossRef]

124. Bailey-Bucktrout, S.L.; Martinez-Llordella, M.; Zhou, X.; Anthony, B.; Rosenthal, W.; Luche, H.; Fehling, H.J.; Bluestone, J.A. Self-antigen-driven activation induces instability of regulatory T cells during an inflammatory autoimmune response. Immunity 2013, 39, 949-962. [CrossRef]

125. Scott, D.W. Genetic Engineering of T Cells for Immune Tolerance. Mol. Ther. Methods Clin. Dev. 2020, 16, 103-107. [CrossRef] [PubMed]

126. Zhang, Q.; Lu, W.; Liang, C.-L.; Chen, Y.; Liu, H.; Qiu, F.; Dai, Z. Chimeric Antigen Receptor (CAR) Treg: A Promising Approach to Inducing Immunological Tolerance. Front. Immunol. 2018, 9, 2359. [CrossRef]

127. Mohseni, Y.R.; Tung, S.L.; Dudreuilh, C.; Lechler, R.I.; Fruhwirth, G.O.; Lombardi, G. The Future of Regulatory T Cell Therapy: Promises and Challenges of Implementing CAR Technology. Front. Immunol. 2020, 11, 1608. [CrossRef]

128. Sadelain, M.; Brentjens, R.; Rivière, I. The basic principles of chimeric antigen receptor design. Cancer Discov. 2013, 3, 388-398. [CrossRef] [PubMed]

129. Boardman, D.A.; Philippeos, C.; Fruhwirth, G.O.; Ibrahim, M.A.A.; Hannen, R.F.; Cooper, D.; Marelli-Berg, F.M.; Watt, F.M.; Lechler, R.I.; Maher, J.; et al. Expression of a Chimeric Antigen Receptor Specific for Donor HLA Class I Enhances the Potency of Human Regulatory T Cells in Preventing Human Skin Transplant Rejection. Am. J. Transplant. 2017, 17, 931-943. [CrossRef] [PubMed]

130. Dawson, N.A.; Lamarche, C.; Hoeppli, R.E.; Bergqvist, P.; Fung, V.C.; McIver, E.; Huang, Q.; Gillies, J.; Speck, M.; Orban, P.C.; et al. Systematic testing and specificity mapping of alloantigen-specific chimeric antigen receptors in regulatory T cells. JCI Insight 2019, 4, 6. [CrossRef]

131. Imura, Y.; Ando, M.; Kondo, T.; Ito, M.; Yoshimura, A. CD19-targeted CAR regulatory T cells suppress B cell pathology without GvHD. JCI Insight 2020, 5, 14. [CrossRef]

132. Boroughs, A.C.; Larson, R.C.; Choi, B.D.; Bouffard, A.A.; Riley, L.S.; Schiferle, E.; Kulkarni, A.S.; Cetrulo, C.L.; Ting, D.; Blazar, B.R.; et al. Chimeric antigen receptor costimulation domains modulate human regulatory T cell function. JCI Insight 2019, 4, 8. [CrossRef]

133. Dawson, N.A.J.; Rosado-Sánchez, I.; Novakovsky, G.E.; Fung, V.C.W.; Huang, Q.; McIver, E.; Sun, G.; Gillies, J.; Speck, M.; Orban, P.C.; et al. Functional effects of chimeric antigen receptor co-receptor signaling domains in human regulatory T cells. Sci. Transl. Med. 2020, 12, 557. [CrossRef]

134. Koristka, S.; Kegler, A.; Bergmann, R.; Arndt, C.; Feldmann, A.; Albert, S.; Cartellieri, M.; Ehninger, A.; Ehninger, G.; Middeke, J.M.; et al. Engrafting human regulatory T cells with a flexible modular chimeric antigen receptor technology. J. Autoimmun. 2018, 90, 116-131. [CrossRef]

135. Meyer, E.H.; Hoeg, R.; Moroz, A.; Xei, B.; Wu, H.-H.; Pawar, R.; Heydari, K.; Miklos, D.B.; Shiraz, P.; Muffly, L.S.; et al. Orca-T, a Precision Treg-Engineered Donor Product, Prevents Acute Gvhd with Less Immunosuppression in an Early Multicenter Experience with Myeloablative HLA-Matched Transplants. Blood 2020, 136, 47-48. [CrossRef]

136. Komatsu, N.; Okamoto, K.; Sawa, S.; Nakashima, T.; Oh-hora, M.; Kodama, T.; Tanaka, S.; Bluestone, J.A.; Takayanagi, H. Pathogenic conversion of Foxp ${ }^{+}$T cells into TH17 cells in autoimmune arthritis. Nat. Med. 2014, 20, 62-68. [CrossRef] [PubMed]

137. Cao, J.; Chen, C.; Zeng, L.; Li, L.; Li, Z.; Xu, K. Engineered regulatory T cells prevent graft-versus-host disease while sparing the graft-versus-leukemia effect after bone marrow transplantation. Leuk. Res. 2010, 34, 1374-1382. [CrossRef] [PubMed]

138. Goodwin, M.; Lee, E.; Lakshmanan, U.; Shipp, S.; Froessl, L.; Barzaghi, F.; Passerini, L.; Narula, M.; Sheikali, A.; Lee, C.M.; et al. CRISPR-based gene editing enables FOXP3 gene repair in IPEX patient cells. Sci. Adv. 2020, 6, 0571. [CrossRef] [PubMed]

139. Loser, K.; Hansen, W.; Apelt, J.; Balkow, S.; Buer, J.; Beissert, S. In vitro-generated regulatory T cells induced by Foxp3-retrovirus infection control murine contact allergy and systemic autoimmunity. Gene Ther. 2005, 12, 1294-1304. [CrossRef] [PubMed]

140. Passerini, L.; Rossi Mel, E.; Sartirana, C.; Fousteri, G.; Bondanza, A.; Naldini, L.; Roncarolo, M.G.; Bacchetta, R. CD4 ${ }^{+}$T cells from IPEX patients convert into functional and stable regulatory T cells by FOXP3 gene transfer. Sci. Transl. Med. 2013, 5, 215. [CrossRef]

141. Honaker, Y.; Hubbard, N.; Xiang, Y.; Fisher, L.; Hagin, D.; Sommer, K.; Song, Y.; Yang, S.J.; Lopez, C.; Tappen, T.; et al. Gene editing to induce FOXP3 expression in human $\mathrm{CD}^{+} \mathrm{T}$ cells leads to a stable regulatory phenotype and function. Sci. Transl. Med. 2020, 12, 546. [CrossRef] 
142. Wright, G.P.; Notley, C.A.; Xue, S.A.; Bendle, G.M.; Holler, A.; Schumacher, T.N.; Ehrenstein, M.R.; Stauss, H.J. Adoptive therapy with redirected primary regulatory T cells results in antigen-specific suppression of arthritis. Proc. Natl. Acad. Sci. USA 2009, 106, 19078-19083. [CrossRef] [PubMed]

143. Fu, W.; Ergun, A.; Lu, T.; Hill, J.A.; Haxhinasto, S.; Fassett, M.S.; Gazit, R.; Adoro, S.; Glimcher, L.; Chan, S.; et al. A multiply redundant genetic switch "locks in" the transcriptional signature of regulatory T cells. Nat. Immunol. 2012, 13, 972-980. [CrossRef]

144. Okada, M.; Kanamori, M.; Someya, K.; Nakatsukasa, H.; Yoshimura, A. Stabilization of Foxp3 expression by CRISPR-dCas9-based epigenome editing in mouse primary T cells. Epigenetics Chromatin 2017, 10, 24. [CrossRef]

145. Forstnerič, V.; Oven, I.; Ogorevc, J.; Lainšček, D.; Praznik, A.; Lebar, T.; Jerala, R.; Horvat, S. CRISPRa-mediated FOXP3 gene upregulation in mammalian cells. Cell Biosci. 2019, 9, 93. [CrossRef] [PubMed]

146. Kressler, C.; Gasparoni, G.; Nordström, K.; Hamo, D.; Salhab, A.; Dimitropoulos, C.; Tierling, S.; Reinke, P.; Volk, H.D.; Walter, J.; et al. Targeted De-Methylation of the FOXP3-TSDR Is Sufficient to Induce Physiological FOXP3 Expression but Not a Functional Treg Phenotype. Front. Immunol. 2021, 11, 1-13. [CrossRef] [PubMed]

147. Takahashi, K.; Tanabe, K.; Ohnuki, M.; Narita, M.; Ichisaka, T.; Tomoda, K.; Yamanaka, S. Induction of pluripotent stem cells from adult human fibroblasts by defined factors. Cell 2007, 131, 861-872. [CrossRef]

148. Haque, M.; Das, J.K.; Xiong, X.; Song, J. Targeting Stem Cell-Derived Tissue-Associated Regulatory T Cells for Type 1 Diabetes Immunotherapy. Curr. Diab. Rep. 2019, 19, 89. [CrossRef]

149. Haque, M.; Song, J.; Fino, K.; Sandhu, P.; Song, X.; Lei, F.; Zheng, S.; Ni, B.; Fang, D.; Song, J. Stem cell-derived tissue-associated regulatory T cells ameliorate the development of autoimmunity. Sci. Rep. 2016, 6, 1-12. [CrossRef]

150. Herold, M.J.; McPherson, K.G.; Reichardt, H.M. Glucocorticoids in T cell apoptosis and function. Cell. Mol. Life Sci. 2006, 63, 60-72. [CrossRef]

151. Tsuda, K.; Yamanaka, K.; Kitagawa, H.; Akeda, T.; Naka, M.; Niwa, K.; Nakanishi, T.; Kakeda, M.; Gabazza, E.C.; Mizutani, H. Calcineurin inhibitors suppress cytokine production from memory $\mathrm{T}$ cells and differentiation of naïve T cells into cytokineproducing mature T cells. PLoS ONE 2012, 7, e31465. [CrossRef]

152. Amini, L.; Greig, J.; Schmueck-Henneresse, M.; Volk, H.-D.D.; Bézie, S.; Reinke, P.; Guillonneau, C.; Wagner, D.L.; Anegon, I. Super-Treg: Toward a New Era of Adoptive Treg Therapy Enabled by Genetic Modifications. Front. Immunol. 2021, 11, 611638. [CrossRef]

153. Basar, R.; Daher, M.; Uprety, N.; Gokdemir, E.; Alsuliman, A.; Ensley, E.; Ozcan, G.; Mendt, M.; Sanabria, M.H.; Kerbauy, L.N.; et al. Large-scale GMP-compliant CRISPR-Cas9-mediated deletion of the glucocorticoid receptor in multivirus-specific T cells. Blood Adv. 2020, 4, 3357-3367. [CrossRef]

154. Kaeuferle, T.; Deisenberger, L.; Jablonowski, L.; Stief, T.A.; Blaeschke, F.; Willier, S.; Feuchtinger, T. CRISPR-Cas9-Mediated Glucocorticoid Resistance in Virus-Specific T Cells for Adoptive T Cell Therapy Posttransplantation. Mol. Ther. 2020, 28, 1965-1973. [CrossRef]

155. Pérol, L.; Martin, G.H.; Maury, S.; Cohen, J.L.; Piaggio, E. Potential limitations of IL-2 administration for the treatment of experimental acute graft-versus-host disease. Immunol. Lett. 2014, 162, 173-184. [CrossRef] [PubMed]

156. Sykes, M.; Romick, M.L.; Sachs, D.H. Interleukin 2 prevents graft-versus-host disease while preserving the graft-versus-leukemia effect of allogeneic T cells. Proc. Natl. Acad. Sci. USA 1990, 87, 5633-5637. [CrossRef]

157. Hirakawa, M.; Matos, T.R.; Liu, H.; Koreth, J.; Kim, H.T.; Paul, N.E.; Murase, K.; Whangbo, J.; Alho, A.C.; Nikiforow, S.; et al. Low-dose IL-2 selectively activates subsets of CD4 ${ }^{+}$Tregs and NK cells. JCI Insight 2016, 1, e89278. [CrossRef] [PubMed]

158. Kennedy-Nasser, A.A.; Ku, S.; Castillo-Caro, P.; Hazrat, Y.; Wu, M.-F.; Liu, H.; Melenhorst, J.; Barrett, A.J.; Ito, S.; Foster, A.; et al. Ultra low-dose IL-2 for GVHD prophylaxis after allogeneic hematopoietic stem cell transplantation mediates expansion of regulatory T cells without diminishing antiviral and antileukemic activity. Clin. Cancer Res. 2014, 20, 2215-2225. [CrossRef]

159. Klatzmann, D.; Abbas, A.K. The promise of low-dose interleukin-2 therapy for autoimmune and inflammatory diseases. Nat. Rev. Immunol. 2015, 15, 283-294. [CrossRef] [PubMed]

160. Liao, W.; Lin, J.-X.; Leonard, W.J. Interleukin-2 at the crossroads of effector responses, tolerance, and immunotherapy. Immunity 2013, 38, 13-25. [CrossRef] [PubMed]

161. Zhao, X.-Y.; Zhao, X.-S.; Wang, Y.-T.; Chen, Y.-H.; Xu, L.-P.; Zhang, X.-H.; Han, W.; Chen, H.; Wang, Y.; Yan, C.-H.; et al. Prophylactic use of low-dose interleukin-2 and the clinical outcomes of hematopoietic stem cell transplantation: A randomized study. Oncoimmunology 2016, 5, e1250992. [CrossRef]

162. Koreth, J.; Kim, H.T.; Jones, K.T.; Lange, P.B.; Reynolds, C.G.; Chammas, M.J.; Dusenbury, K.; Whangbo, J.; Nikiforow, S.; Alyea, E.P.; et al. Efficacy, durability, and response predictors of low-dose interleukin-2 therapy for chronic graft-versus-host disease. Blood 2016, 128, 130-137. [CrossRef] [PubMed]

163. Simonetta, F.; Alvarez, M.; Negrin, R.S. Natural Killer Cells in Graft-versus-Host-Disease after Allogeneic Hematopoietic Cell Transplantation. Front. Immunol. 2017, 8, 465. [CrossRef] [PubMed]

164. Bell, C.J.M.; Sun, Y.; Nowak, U.M.; Clark, J.; Howlett, S.; Pekalski, M.L.; Yang, X.; Ast, O.; Waldhauer, I.; FreimoserGrundschober, A.; et al. Sustained in vivo signaling by long-lived IL-2 induces prolonged increases of regulatory T cells. J. Autoimmun. 2015, 56, 66-80. [CrossRef] [PubMed]

165. Lotze, M.T.; Matory, Y.L.; Ettinghausen, S.E.; Rayner, A.A.; Sharrow, S.O.; Seipp, C.A.; Custer, M.C.; Rosenberg, S.A. In vivo administration of purified human interleukin 2. II. Half life, immunologic effects, and expansion of peripheral lymphoid cells in vivo with recombinant IL 2. J. Immunol. 1985, 135, 2865-2875. 
166. Ward, N.C.; Yu, A.; Moro, A.; Ban, Y.; Chen, X.; Hsiung, S.; Keegan, J.; Arbanas, J.M.; Loubeau, M.; Thankappan, A.; et al. IL-2/CD25: A Long-Acting Fusion Protein That Promotes Immune Tolerance by Selectively Targeting the IL-2 Receptor on Regulatory T Cells. J. Immunol. 2018, 201, 2579-2592. [CrossRef]

167. Pilat, N.; Wiletel, M.; Weijler, A.M.; Steiner, R.; Mahr, B.; Warren, J.; Corpuz, T.M.; Wekerle, T.; Webster, K.E.; Sprent, J. Tregmediated prolonged survival of skin allografts without immunosuppression. Proc. Natl. Acad. Sci. USA 2019, 116, 13508-13516. [CrossRef]

168. Webster, K.E.; Walters, S.; Kohler, R.E.; Mrkvan, T.; Boyman, O.; Surh, C.D.; Grey, S.T.; Sprent, J. In vivo expansion of T reg cells with IL-2-mAb complexes: Induction of resistance to EAE and long-term acceptance of islet allografts without immunosuppression. J. Exp. Med. 2009, 206, 751-760. [CrossRef]

169. Yokoyama, Y.; Iwasaki, T.; Kitano, S.; Satake, A.; Nomura, S.; Furukawa, T.; Matsui, K.; Sano, H. IL-2-Anti-IL-2 Monoclonal Antibody Immune Complexes Inhibit Collagen-Induced Arthritis by Augmenting Regulatory T Cell Functions. J. Immunol. 2018, 201, 1899-1906. [CrossRef]

170. Peterson, L.B.; Bell, C.J.M.; Howlett, S.K.; Pekalski, M.L.; Brady, K.; Hinton, H.; Sauter, D.; Todd, J.A.; Umana, P.; Ast, O.; et al. A long-lived IL-2 mutein that selectively activates and expands regulatory $\mathrm{T}$ cells as a therapy for autoimmune disease. $J$. Autoimmun. 2018, 95, 1-14. [CrossRef]

171. Sockolosky, J.T.; Trotta, E.; Parisi, G.; Picton, L.; Su, L.L.; Le, A.C.; Chhabra, A.; Silveria, S.L.; George, B.M.; King, I.C.; et al. Selective targeting of engineered T cells using orthogonal IL-2 cytokine-receptor complexes. Science 2018, 359, $1037-1042$. [CrossRef]

172. Hirai, T.; Ramos, T.L.; Lin, P.-Y.; Simonetta, F.; Su, L.L.; Picton, L.K.; Baker, J.; Lin, J.; Li, P.; Seo, K.; et al. Selective expansion of regulatory $\mathrm{T}$ cells using an orthogonal IL-2/IL-2 receptor system facilitates transplantation tolerance. J. Clin. Investig. 2021, 131, e139991. [CrossRef] [PubMed]

173. Byersdorfer, C.A.; Tkachev, V.; Opipari, A.W.; Goodell, S.; Swanson, J.; Sandquist, S.; Glick, G.D.; Ferrara, J.L.M. Effector T cells require fatty acid metabolism during murine graft-versus-host disease. Blood 2013, 122, 3230-3237. [CrossRef]

174. Hippen, K.L.; Aguilar, E.G.; Rhee, S.Y.; Bolivar-wagers, S.; Blazar, B.R. Distinct Regulatory and Effector T Cell Metabolic Demands during Graft-Versus-Host Disease. Trends Immunol. 2020, 41, 77-91. [CrossRef]

175. Nguyen, H.D.; Kuril, S.; Bastian, D.; Yu, X.-Z. T-Cell Metabolism in Hematopoietic Cell Transplantation. Front. Immunol. 2018, 9 , 176. [CrossRef] [PubMed]

176. Saha, A.; O'Connor, R.S.; Thangavelu, G.; Lovitch, S.B.; Dandamudi, D.B.; Wilson, C.B.; Vincent, B.G.; Tkachev, V.; Pawlicki, J.M.; Furlan, S.N.; et al. Programmed death ligand-1 expression on donor T cells drives graft-versus-host disease lethality. J. Clin. Investig. 2016, 126, 2642-2660. [CrossRef] [PubMed]

177. Tijaro-Ovalle, N.M.; Karantanos, T.; Wang, H.-T.; Boussiotis, V.A. Metabolic Targets for Improvement of Allogeneic Hematopoietic Stem Cell Transplantation and Graft-vs.-Host Disease. Front. Immunol. 2019, 10, 295. [CrossRef]

178. Brown, R.A.; Byersdorfer, C.A. Metabolic Pathways in Alloreactive T Cells. Front. Immunol. 2020, 11, 1517. [CrossRef] [PubMed]

179. Gatza, E.; Wahl, D.R.; Opipari, A.W.; Sundberg, T.B.; Reddy, P.; Liu, C.; Glick, G.D.; Ferrara, J.L.M. Manipulating the bioenergetics of alloreactive T cells causes their selective apoptosis and arrests graft-versus-host disease. Sci. Transl. Med. 2011, 3, 67. [CrossRef]

180. Gerriets, V.A.; Kishton, R.J.; Nichols, A.G.; Macintyre, A.N.; Inoue, M.; Ilkayeva, O.; Winter, P.S.; Liu, X.; Priyadharshini, B.; Slawinska, M.E.; et al. Metabolic programming and PDHK1 control CD4 ${ }^{+}$T cell subsets and inflammation. J. Clin. Investig. 2015, 125, 194-207. [CrossRef]

181. Michalek, R.D.; Gerriets, V.A.; Jacobs, S.R.; Macintyre, A.N.; MacIver, N.J.; Mason, E.F.; Sullivan, S.A.; Nichols, A.G.; Rathmell, J.C. Cutting edge: Distinct glycolytic and lipid oxidative metabolic programs are essential for effector and regulatory CD4 ${ }^{+} \mathrm{T}$ cell subsets. J. Immunol. 2011, 186, 3299-3303. [CrossRef]

182. Kishore, M.; Cheung, K.C.P.; Fu, H.; Bonacina, F.; Wang, G.; Coe, D.; Ward, E.J.; Colamatteo, A.; Jangani, M.; Baragetti, A.; et al. Regulatory T Cell Migration Is Dependent on Glucokinase-Mediated Glycolysis. Immunity 2017, 47, 875-889.e10. [CrossRef] [PubMed]

183. Shi, L.Z.; Wang, R.; Huang, G.; Vogel, P.; Neale, G.; Green, D.R.; Chi, H. HIF1alpha-dependent glycolytic pathway orchestrates a metabolic checkpoint for the differentiation of TH17 and Treg cells. J. Exp. Med. 2011, 208, 1367-1376. [CrossRef]

184. Herrero-Sánchez, M.C.; Rodríguez-Serrano, C.; Almeida, J.; San Segundo, L.; Inogés, S.; Santos-Briz, Á.; García-Briñón, J.; Corchete, L.A.; San Miguel, J.F.; Del Cañizo, C.; et al. Targeting of PI3K/AKT/mTOR pathway to inhibit T cell activation and prevent graft-versus-host disease development. J. Hematol. Oncol. 2016, 9, 113. [CrossRef]

185. Blazar, B.R.; Taylor, P.A.; Panoskaltsis-Mortari, A.; Vallera, D.A. Rapamycin inhibits the generation of graft-versus-host diseaseand graft-versus-leukemia-causing T cells by interfering with the production of Th1 or Th1 cytotoxic cytokines. J. Immunol. 1998, 160, 5355-5365.

186. Shin, H.-J.; Baker, J.; Leveson-Gower, D.B.; Smith, A.T.; Sega, E.I.; Negrin, R.S. Rapamycin and IL-2 reduce lethal acute graftversus-host disease associated with increased expansion of donor type CD4+CD25+Foxp3 ${ }^{+}$regulatory T cells. Blood 2011, 118, 2342-2350. [CrossRef]

187. Fujiwara, H.; Docampo, M.D.; Riwes, M.; Peltier, D.; Toubai, T.; Henig, I.; Wu, S.J.; Kim, S.; Taylor, A.; Brabbs, S.; et al. Microbial metabolite sensor GPR43 controls severity of experimental GVHD. Nat. Commun. 2018, 9, 3674. [CrossRef] 
188. Furusawa, Y.; Obata, Y.; Fukuda, S.; Endo, T.A.; Nakato, G.; Takahashi, D.; Nakanishi, Y.; Uetake, C.; Kato, K.; Kato, T.; et al. Commensal microbe-derived butyrate induces the differentiation of colonic regulatory T cells. Nature 2013, 504, 446-450. [CrossRef]

189. Jacob, N.; Jaiswal, S.; Maheshwari, D.; Nallabelli, N.; Khatri, N.; Bhatia, A.; Bal, A.; Malik, V.; Verma, S.; Kumar, R.; et al. Butyrate induced Tregs are capable of migration from the GALT to the pancreas to restore immunological tolerance during type-1 diabetes. Sci. Rep. 2020, 10, 19120. [CrossRef] [PubMed]

190. Kespohl, M.; Vachharajani, N.; Luu, M.; Harb, H.; Pautz, S.; Wolff, S.; Sillner, N.; Walker, A.; Schmitt-Kopplin, P.; Boettger, T.; et al. The Microbial Metabolite Butyrate Induces Expression of Th1-Associated Factors in CD4 ${ }^{+}$T Cells. Front. Immunol. 2017, 8, 1036. [CrossRef] [PubMed]

191. Mathewson, N.D.; Jenq, R.; Mathew, A.V.; Koenigsknecht, M.; Hanash, A.; Toubai, T.; Oravecz-Wilson, K.; Wu, S.-R.; Sun, Y.; Rossi, C.; et al. Gut microbiome-derived metabolites modulate intestinal epithelial cell damage and mitigate graft-versus-host disease. Nat. Immunol. 2016, 17, 505-513. [CrossRef] [PubMed]

192. Park, M.-J.; Lee, S.-Y.; Moon, S.-J.; Son, H.-J.; Lee, S.-H.; Kim, E.-K.; Byun, J.-K.; Shin, D.Y.; Park, S.-H.; Yang, C.-W.; et al. Metformin attenuates graft-versus-host disease via restricting mammalian target of rapamycin/signal transducer and activator of transcription 3 and promoting adenosine monophosphate-activated protein kinase-autophagy for the balance between $\mathrm{T}$ helper 17 an. Transl. Res. 2016, 173, 115-130. [CrossRef]

193. Johnson, M.O.; Wolf, M.M.; Madden, M.Z.; Andrejeva, G.; Sugiura, A.; Contreras, D.C.; Maseda, D.; Liberti, M.V.; Paz, K.; Kishton, R.J.; et al. Distinct Regulation of Th17 and Th1 Cell Differentiation by Glutaminase-Dependent Metabolism. Cell 2018, 175, 1780-1795.e19. [CrossRef] [PubMed]

194. Klysz, D.; Tai, X.; Robert, P.A.; Craveiro, M.; Cretenet, G.; Oburoglu, L.; Mongellaz, C.; Floess, S.; Fritz, V.; Matias, M.I.; et al. Glutamine-dependent $\alpha$-ketoglutarate production regulates the balance between $\mathrm{T}$ helper 1 cell and regulatory $\mathrm{T}$ cell generation. Sci. Signal. 2015, 8, ra97. [CrossRef] [PubMed]

195. Nakaya, M.; Xiao, Y.; Zhou, X.; Chang, J.-H.; Chang, M.; Cheng, X.; Blonska, M.; Lin, X.; Sun, S.-C. Inflammatory T cell responses rely on amino acid transporter ASCT2 facilitation of glutamine uptake and mTORC1 kinase activation. Immunity 2014, 40, 692-705. [CrossRef] [PubMed]

196. Priyadharshini, B.; Loschi, M.; Newton, R.H.; Zhang, J.-W.; Finn, K.K.; Gerriets, V.A.; Huynh, A.; Rathmell, J.C.; Blazar, B.R.; Turka, L.A. Cutting Edge: TGF- $\beta$ and Phosphatidylinositol 3-Kinase Signals Modulate Distinct Metabolism of Regulatory T Cell Subsets. J. Immunol. 2018, 201, 2215-2219. [CrossRef]

197. Tanimine, N.; Germana, S.K.; Fan, M.; Hippen, K.; Blazar, B.R.; Markmann, J.F.; Turka, L.A.; Priyadharshini, B. Differential effects of 2-deoxy-D-glucose on in vitro expanded human regulatory T cell subsets. PLoS ONE 2019, 14, e0217761. [CrossRef]

198. Trzonkowski, P.; Bieniaszewska, M.; Juścińska, J.; Dobyszuk, A.; Krzystyniak, A.; Marek, N.; Myśliwska, J.; Hellmann, A. First-inman clinical results of the treatment of patients with graft versus host disease with human ex vivo expanded CD4 ${ }^{+} \mathrm{CD} 25^{+} \mathrm{CD} 127^{-}$ T regulatory cells. Clin. Immunol. 2009, 133, 22-26. [CrossRef]

199. Canavan, J.B.; Scottà, C.; Vossenkämper, A.; Goldberg, R.; Elder, M.J.; Shoval, I.; Marks, E.; Stolarczyk, E.; Lo, J.W.; Powell, N.; et al. Developing in vitro expanded CD45RA+ regulatory T cells as an adoptive cell therapy for Crohn's disease. Gut 2016, 65, 584-594. [CrossRef]

200. Gu, J.; Ni, X.; Pan, X.; Lu, H.; Lu, Y.; Zhao, J.; Guo Zheng, S.; Hippen, K.L.; Wang, X.; Lu, L. Human CD39hi regulatory T cells present stronger stability and function under inflammatory conditions. Cell. Mol. Immunol. 2017, 14, 521-528. [CrossRef]

201. Haase, D.; Puan, K.J.; Starke, M.; Lai, T.S.; Soh, M.Y.L.; Karunanithi, I.; San Luis, B.; Poh, T.Y.; Yusof, N.; Yeap, C.H.; et al. Large-scale Isolation of Highly Pure “Untouched” Regulatory T Cells in a GMP Environment for Adoptive Cell Therapy. J. Immunother. 2015, 38, 250-258. [CrossRef]

202. Hoffmann, P.; Eder, R.; Boeld, T.J.; Doser, K.; Piseshka, B.; Andreesen, R.; Edinger, M. Only the CD45RA+ subpopulation of $\mathrm{CD} 4{ }^{+} \mathrm{CD} 25^{\text {high }} \mathrm{T}$ cells gives rise to homogeneous regulatory T-cell lines upon in vitro expansion. Blood 2006, 108, $4260-4267$. [CrossRef]

203. Baeten, P.; Zeebroeck, L.; Van Kleinewietfeld, M.; Hellings, N.; Broux, B. Improving the Efficacy of Regulatory T Cell Therapy. Clin. Rev. Allergy Immunol. 2021, 6, 1-19. [CrossRef]

204. Fritsche, E.; Volk, H.D.; Reinke, P.; Abou-El-Enein, M. Toward an Optimized Process for Clinical Manufacturing of CAR-Treg Cell Therapy. Trends Biotechnol. 2020, 38, 1099-1112. [CrossRef]

205. Iyer, R.K.; Bowles, P.A.; Kim, H.; Dulgar-Tulloch, A. Industrializing Autologous Adoptive Immunotherapies: Manufacturing Advances and Challenges. Front. Med. 2018, 5, 150. [CrossRef]

206. Di Ianni, M.; Falzetti, F.; Carotti, A.; Terenzi, A.; Castellino, F.; Bonifacio, E.; Del Papa, B.; Zei, T.; Ostini, R.I.; Cecchini, D.; et al. Tregs prevent GVHD and promote immune reconstitution in HLA-haploidentical transplantation. Blood 2011, 117, $3921-3928$. [CrossRef]

207. Hara, M.; Kingsley, C.I.; Niimi, M.; Read, S.; Turvey, S.E.; Bushell, A.R.; Morris, P.J.; Powrie, F.; Wood, K.J. IL-10 is required for regulatory $\mathrm{T}$ cells to mediate tolerance to alloantigens in vivo. J. Immunol. 2001, 166, 3789-3796. [CrossRef]

208. Graca, L.; Thompson, S.; Lin, C.-Y.; Adams, E.; Cobbold, S.P.; Waldmann, H. Both CD4(+)CD25(+) and CD4(+)CD25(-) regulatory cells mediate dominant transplantation tolerance. J. Immunol. 2002, 168, 5558-5565. [CrossRef] [PubMed]

209. Hoffmann, P.; Eder, R.; Kunz-Schughart, L.A.; Andreesen, R.; Edinger, M. Large-scale in vitro expansion of polyclonal human CD4(+)CD25high regulatory T cells. Blood 2004, 104, 895-903. [CrossRef] [PubMed] 
210. MacDonald, K.N.; Piret, J.M.; Levings, M.K. Methods to manufacture regulatory T cells for cell therapy. Clin. Exp. Immunol. 2019, 197, 52-63. [CrossRef]

211. Miyara, M.; Yoshioka, Y.; Kitoh, A.; Shima, T.; Wing, K.; Niwa, A.; Parizot, C.; Taflin, C.; Heike, T.; Valeyre, D.; et al. Functional delineation and differentiation dynamics of human $\mathrm{CD}^{+} \mathrm{T}$ cells expressing the FoxP3 transcription factor. Immunity 2009, 30, 899-911. [CrossRef]

212. Hippen, K.L.; Furlan, S.N.; Roychoudhuri, R.; Wang, E.; Zhang, Y.; Osborn, M.J.; Merkel, S.C.; Hani, S.; MacMillan, M.L.; Cichocki, F.; et al. Multiply restimulated human thymic regulatory $\mathrm{T}$ cells express distinct signature regulatory T-cell transcription factors without evidence of exhaustion. Cytotherapy 2021, 6, 20. [CrossRef]

213. Miyara, M.; Chader, D.; Burlion, A.; Goldstein, J.; Sterlin, D.; Norol, F.; Trebeden-Nègre, H.; Claër, L.; Sakaguchi, S.; Marodon, G.; et al. Combination of IL-2, rapamycin, DNA methyltransferase and histone deacetylase inhibitors for the expansion of human regulatory T cells. Oncotarget 2017, 8, 104733-104744. [CrossRef]

214. Pierini, A.; Colonna, L.; Alvarez, M.; Schneidawind, D.; Nishikii, H.; Baker, J.; Pan, Y.; Florek, M.; Kim, B.-S.; Negrin, R.S. Donor Requirements for Regulatory T Cell Suppression of Murine Graft-versus-Host Disease. J. Immunol. 2015, 195, 347-355. [CrossRef]

215. Gołąb, K.; Grose, R.; Placencia, V.; Wickrema, A.; Solomina, J.; Tibudan, M.; Konsur, E.; Ciepły, K.; Marek-Trzonkowska, N.; Trzonkowski, P.; et al. Cell banking for regulatory T cell-based therapy: Strategies to overcome the impact of cryopreservation on the Treg viability and phenotype. Oncotarget 2018, 9, 9728-9740. [CrossRef] [PubMed]

216. MacDonald, K.N.; Ivison, S.; Hippen, K.L.; Hoeppli, R.E.; Hall, M.; Zheng, G.; Dijke, I.E.; Aklabi, M.; Al Freed, D.H.; Rebeyka, I.; et al. Cryopreservation timing is a critical process parameter in a thymic regulatory T-cell therapy manufacturing protocol. Cytotherapy 2019, 21, 1216-1233. [CrossRef] [PubMed]

217. Zeiser, R.; Nguyen, V.H.; Beilhack, A.; Buess, M.; Schulz, S.; Baker, J.; Contag, C.H.; Negrin, R.S. Inhibition of CD4 ${ }^{+}$CD25 ${ }^{+}$ regulatory T-cell function by calcineurin-dependent interleukin-2 production. Blood 2006, 108, 390-399. [CrossRef]

218. Battaglia, M.; Stabilini, A.; Roncarolo, M.-G. Rapamycin selectively expands CD $4^{+} \mathrm{CD} 25^{+} \mathrm{FoxP} 3^{+}$regulatory T cells. Blood 2005, 105, 4743-4748. [CrossRef]

219. Zeiser, R.; Leveson-Gower, D.B.; Zambricki, E.A.; Kambham, N.; Beilhack, A.; Loh, J.; Hou, J.-Z.; Negrin, R.S. Differential impact of mammalian target of rapamycin inhibition on $\mathrm{CD}^{+} \mathrm{CD}_{2} 5^{+} \mathrm{Foxp}^{+}$regulatory $\mathrm{T}$ cells compared with conventional $\mathrm{CD} 4^{+} \mathrm{T}$ cells. Blood 2008, 111, 453-462. [CrossRef]

220. Singh, K.; Stempora, L.; Harvey, R.D.; Kirk, A.D.; Larsen, C.P.; Blazar, B.R.; Kean, L.S. Superiority of rapamycin over tacrolimus in preserving nonhuman primate Treg half-life and phenotype after adoptive transfer. Am. J. Transplant. 2014, 14, $2691-2703$. [CrossRef] [PubMed]

221. Tkachev, V.; Furlan, S.N.; Watkins, B.; Hunt, D.J.; Zheng, H.B.; Panoskaltsis-Mortari, A.; Betz, K.; Brown, M.; Schell, J.B.; Zeleski, K.; et al. Combined OX40L and mTOR blockade controls effector T cell activation while preserving Treg reconstitution after transplant. Sci. Transl. Med. 2017, 9, 408. [CrossRef]

222. Betts, B.C.; Bastian, D.; Iamsawat, S.; Nguyen, H.; Heinrichs, J.L.; Wu, Y.; Daenthanasanmak, A.; Veerapathran, A.; O’Mahony, A.; Walton, K.; et al. Targeting JAK2 reduces GVHD and xenograft rejection through regulation of T cell differentiation. Proc. Natl. Acad. Sci. USA 2018, 115, 1582-1587. [CrossRef] [PubMed]

223. Choi, J.; Cooper, M.L.; Staser, K.; Ashami, K.; Vij, K.R.; Wang, B.; Marsala, L.; Niswonger, J.; Ritchey, J.; Alahmari, B.; et al. Baricitinib-induced blockade of interferon gamma receptor and interleukin-6 receptor for the prevention and treatment of graft-versus-host disease. Leukemia 2018, 32, 2483-2494. [CrossRef] [PubMed]

224. Choi, S.W.; Gatza, E.; Hou, G.; Sun, Y.; Whitfield, J.; Song, Y.; Oravecz-Wilson, K.; Tawara, I.; Dinarello, C.A.; Reddy, P. Histone deacetylase inhibition regulates inflammation and enhances Tregs after allogeneic hematopoietic cell transplantation in humans. Blood 2015, 125, 815-819. [CrossRef]

225. Flynn, R.; Paz, K.; Du, J.; Reichenbach, D.K.; Taylor, P.A.; Panoskaltsis-Mortari, A.; Vulic, A.; Luznik, L.; MacDonald, K.K.P.; Hill, G.R.; et al. Targeted Rho-associated kinase 2 inhibition suppresses murine and human chronic GVHD through a Stat3dependent mechanism. Blood 2016, 127, 2144-2154. [CrossRef] [PubMed]

226. Furlan, S.N.; Singh, K.; Lopez, C.; Tkachev, V.; Hunt, D.J.; Hibbard, J.; Betz, K.M.; Blazar, B.R.; Trapnell, C.; Kean, L.S. IL-2 enhances ex vivo-expanded regulatory T-cell persistence after adoptive transfer. Blood Adv. 2020, 4, 1594-1605. [CrossRef] [PubMed]

227. Greco, R.; Lorentino, F.; Albanese, S.; Lupo Stanghellini, M.T.; Giglio, F.; Piemontese, S.; Clerici, D.; Lazzari, L.; Marcatti, M.; Mastaglio, S.; et al. Posttransplantation Cyclophosphamide- and Sirolimus-Based Graft-Versus-Host-Disease Prophylaxis in Allogeneic Stem Cell Transplant. Transplant. Cell. Ther. 2021, 20, 1828-1834. [CrossRef]

228. Robinson, T.M.; O’Donnell, P.V.; Fuchs, E.J.; Luznik, L. Haploidentical bone marrow and stem cell transplantation: Experience with post-transplantation cyclophosphamide. Semin. Hematol. 2016, 53, 90-97. [CrossRef] [PubMed]

229. Theil, A.; Tuve, S.; Oelschlägel, U.; Maiwald, A.; Döhler, D.; Oßmann, D.; Zenkel, A.; Wilhelm, C.; Middeke, J.M.; Shayegi, N.; et al. Adoptive transfer of allogeneic regulatory T cells into patients with chronic graft-versus-host disease. Cytotherapy 2015, 17, 473-486. [CrossRef]

230. Kellner, J.N.; Delemarre, E.M.; Yvon, E.; Nierkens, S.; Boelens, J.J.; McNiece, I.; Olson, A.; Nieto, Y.; Ciurea, S.; Popat, U.; et al. Third party, umbilical cord blood derived regulatory T-cells for prevention of graft versus host disease in allogeneic hematopoietic stem cell transplantation: Feasibility, safety and immune reconstitution. Oncotarget 2018, 9, 35611-35622. [CrossRef] 
231. Edinger, M.; Hoffmann, P. Regulatory T cells in stem cell transplantation: Strategies and first clinical experiences. Curr. Opin. Immunol. 2011, 23, 679-684. [CrossRef] [PubMed]

232. Dees, S.; Ganesan, R.; Singh, S.; Grewal, I.S. Regulatory T cell targeting in cancer: Emerging strategies in immunotherapy. Eur. J. Immunol. 2021, 51, 280-291. [CrossRef]

233. Eyquem, J.; Mansilla-Soto, J.; Giavridis, T.; Van Der Stegen, S.J.C.C.; Hamieh, M.; Cunanan, K.M.; Odak, A.; Gönen, M.; Sadelain, M. Targeting a CAR to the TRAC locus with CRISPR/Cas9 enhances tumour rejection. Nature 2017, 543, 113-117. [CrossRef] [PubMed]

234. Osborn, M.J.; Webber, B.R.; Knipping, F.; Lonetree, C.; Tennis, N.; Defeo, A.P.; Mcelroy, A.N.; Starker, C.G.; Lee, C.; Merkel, S.; et al. Evaluation of TCR Gene Editing Achieved by TALENs, CRISPR/Cas9, and megaTAL Nucleases. Mol Ther 2016, 24, 570-581. [CrossRef] [PubMed]

235. Roybal, K.T.; Williams, J.Z.; Morsut, L.; Rupp, L.J.; Kolinko, I.; Choe, J.H.; Walker, W.J.; McNally, K.A.; Lim, W.A. Engineering T Cells with Customized Therapeutic Response Programs Using Synthetic Notch Receptors. Cell 2016, 167, 419-432.e16. [CrossRef] [PubMed]

236. Oberholtzer, N.; Atkinson, C.; Nadig, S.N. Adoptive Transfer of Regulatory Immune Cells in Organ Transplantation. Front. Immunol. 2021, 12, 1-16. [CrossRef] [PubMed]

237. Marx, U.; Akabane, T.; Andersson, T.B.; Baker, E.; Beilmann, M.; Beken, S.; Brendler-Schwaab, S.; Cirit, M.; David, R.; Dehne, E.-M.; et al. Biology-inspired microphysiological systems to advance patient benefit and animal welfare in drug development. ALTEX 2020, 37, 365-394. [CrossRef] 